\title{
Article \\ There Is Strength in Numbers: Quantitation of Fc Gamma Receptors on Murine Tissue-Resident Macrophages
}

\author{
Christof Vorsatz $^{1,+}\left(\mathbb{D}\right.$, Niklas Friedrich ${ }^{1,+}+\mathbb{C}$, Falk Nimmerjahn ${ }^{1,2}$ and Markus Biburger ${ }^{1,2, * \mathbb{C}}$ \\ 1 Division of Genetics, Department of Biology, Friedrich-Alexander University Erlangen-Nürnberg, \\ 91058 Erlangen, Germany; christof.vorsatz@fau.de (C.V.); nik.f.friedrich@fau.de (N.F.); \\ falk.nimmerjahn@fau.de (F.N.) \\ 2 Medical Immunology Campus Erlangen, Friedrich-Alexander University Erlangen-Nürnberg, \\ 91052 Erlangen, Germany \\ * Correspondence: markus.biburger@fau.de; Tel.: +49-0131-85-25049 \\ + C.V. and N.F. contributed equally to this work.
}

Citation: Vorsatz, C.; Friedrich, N.; Nimmerjahn, F.; Biburger, M. There Is Strength in Numbers: Quantitation of Fc Gamma Receptors on Murine Tissue-Resident Macrophages. Int. J. Mol. Sci. 2021, 22, 12172. https:// doi.org/10.3390/ijms222212172

Academic Editor: Mike Barbeck

Received: 24 September 2021

Accepted: 3 November 2021

Published: 10 November 2021

Publisher's Note: MDPI stays neutral with regard to jurisdictional claims in published maps and institutional affiliations.

Copyright: (c) 2021 by the authors. Licensee MDPI, Basel, Switzerland. This article is an open access article distributed under the terms and conditions of the Creative Commons Attribution (CC BY) license (https:// creativecommons.org/licenses/by/ $4.0 /)$
Abstract: Many of the effector functions of antibodies rely on the binding of antibodies/immune complexes to cellular $\mathrm{F}_{\mathrm{c}} \gamma$ receptors ( $\mathrm{Fc} \gamma \mathrm{Rs}$ ). Since the majority of innate immune effector cells express both activating and inhibitory Fc receptors, the outcome of the binding of immune complexes to cells of a given population is influenced by the relative affinities of the respective IgG subclasses to these receptors, as well as by the numbers of activating and inhibitory Fc $\gamma$ Rs on the cell surface. A group of immune cells that has come into focus more recently is the various subsets of tissueresident macrophages. The central functions of $\mathrm{Fc}_{\mathrm{c}} \mathrm{R}$ s on tissue macrophages include the clearance of opsonized pathogens, the removal of small immune complexes from the circulation and the depletion of antibody-opsonized cells in the therapy of autoimmunity and cancer. Despite these essential functions of Fc $\gamma$ Rs on tissue-resident macrophages, an in-depth quantification of Fc $\gamma$ Rs is lacking. Thus, the aim of our current study was to quantify the various $\mathrm{F}_{\mathrm{c}} \gamma$ receptors on macrophages in murine liver, lung, kidney, brain, skin and spleen. Our study identified a pronounced heterogeneity between $\mathrm{F}_{\mathrm{c}} \gamma \mathrm{R}$ expression patterns of the different tissue macrophages, which may reflect their specialized functions within their unique niches in different organ environments.

Keywords: Fc receptors; antibodies; macrophages; alveolar macrophages; interstitial macrophages; Kupffer cells; splenic macrophages; kidney resident macrophages; microglia; Langerhans cells; dermal macrophages

\section{Introduction}

Macrophages (M $\Phi)$ form a network of heterogeneous immunologic sentinels in all tissues, where they perform niche and tissue specific functions. This involves classical immune functions like combating infections [1], the resolution of inflammation [2,3], surveillance against tumors [4,5] and mediation of antibody-dependent antitumoral [6] or cell-depleting [7] effector functions. In addition, besides their immunologic functions, tissue-resident macrophages play pivotal roles in tissue homeostasis [8-10] and can modulate angiogenesis and lymphangiogenesis [11,12]. However, macrophages are also critically involved in various disorders, like cardiovascular [13] and pulmonary [14] diseases, type 2 diabetes [15] and cancer, where they can promote cancer initiation, malignant progression, tumor cell migration, in- and intravasation and the suppression of antitumor immunity (see, e.g., Reference [16]). Most tissue macrophages-with the exception of intestinal M $\Phi$, which are constantly seeded by bone marrow-derived monocytes [17,18] —are derived from yolk sacs or fetal liver precursors that persist into adulthood as resident populations that are maintained by in situ proliferation [19-24]. After birth, bone marrow-derived monocytes can replenish certain tissue-resident $\mathrm{M} \Phi$ following tissue injury, infection and inflammation (reviewed, e.g., in Reference [25]). Among the innate immune effector cells, macrophages 
express the broadest set of cell surface receptors, including pattern recognition receptors and complement and Fc receptors, allowing them to directly or indirectly detect pathogens. The family of murine Fc $\gamma$ R includes the inhibitory Fc $\gamma$ RIIb (CD32b) and the activating receptors Fc $\gamma$ RI, III and IV. Whereas Fc $\gamma$ RIIb modulates signaling via an intracellular immunomodulatory tyrosine-based inhibitory motif (ITIM) in the same polypeptide chain as the ligand-binding domain, all activating Fc $\gamma \mathrm{R}$ signal via an activating ITAM motif provided by the accessory Fc receptor gamma chain [26]. While immune complexes (IC) can bind to all murine Fc $\gamma$ R, including the low/medium affinity receptors Fc $\gamma$ RIIb, Fc $\gamma$ RIII and Fc $\gamma$ RIV, monomeric IgG exclusively binds to high-affinity Fc $\gamma$ RI (reviewed, e.g., in References $[27,28])$ and may be occupied by circulating IgG, at least in the blood. A central function of $F c \gamma$ Rs on macrophages is to promote the clearance of opsonized pathogens in the periphery $[29,30]$. Likewise, opsonized host cells—for instance, cells that express viral antigens upon infection - can be killed via antibody-dependent cell-mediated cytotoxicity (ADCC) [31]. Along the same lines, macrophages have been identified as key effector cells for removing opsonized target cells in a variety of mouse model systems (e.g., References $[6,7,32,33])$. Apart from ADCC and phagocytosis, Fc $\gamma$ Rs on macrophages may also be involved in modulating $M \Phi$ polarization. Whereas the engagement of activating Fc $\gamma$ Rs induces the production of proinflammatory cytokines, the binding of immune complexes together with an engagement of Toll-like receptors (TLR) has been shown to drive the polarization of macrophages to a so-called M2b phenotype, also referred to as "regulatory macrophages". These macrophages produced high levels of the immunosuppressive cytokine IL-10 and downmodulate TLR-induced IL-12 production [34,35]. Of note, with respect to infection, the antibody-mediated triggering of Fc $\gamma \mathrm{R}$ may have contrasting effects: On the one hand, the opsonization of pathogens that normally evade degradation in lysosomes like Legionella pneumophila and Mycobacterium bovis bacillus Calmette-Guérin results in targeting them at lysosomes, where they are efficiently eliminated [30]. On the other hand, the opsonization of pathogens like dengue virus with antibodies may cause increased uptake via Fc $\gamma R$ engagement, resulting in antibody-enhanced infection [36-38].

In summary, $\mathrm{IgG}$ binding to $\mathrm{Fc} \gamma \mathrm{Rs}$ on macrophages is responsible for a wide range of effector functions underlying the activity of pathogen, autoreactive and therapeutic IgG antibody species. Importantly, the net effect of $\mathrm{Fc} \gamma \mathrm{R}$ engagement by IgG immune complexes on any given macrophage is determined by the balance between signals from activating ITAM-bearing Fc $\gamma$ Rs and inhibitory ITIM-bearing Fc $\gamma$ RIlb. This balance can be influenced by the size, IgG valency and subtype composition (due to different affinities between the different receptors and IgG subtypes) of the triggering immune complex but, obviously, also by the respective number of receptors on the cell surface [39-42].

Various groups have presented qualitative information on which Fc $\gamma$ receptors are expressed on the various murine tissue macrophages and, often, data on mRNA expression via quantitative PCR and/or semi-quantitative flow cytometry data on the surface expression of murine Fc $\gamma$ Rs (see, e.g., References [43-50]). However, the relative mRNA expression levels of the different $\mathrm{F} \gamma \gamma \mathrm{Rs}$ do not necessarily translate one-to-one into ratios of receptor numbers on the cell surface. Data on the fluorescence intensities upon the binding of fluorescently labeled antibody conjugates are very valid for the comparison of relative expression levels of the same antigen on different cells or under different physiological conditions. However, as described in more detail in Reference [42], mainly due to inherent variations between the different antibody conjugates with respect to their specific fluorescence (i.e., fluorescence intensity per molecule), the quantitative comparison of different receptors is hampered. In addition, both methods do not provide any information on the actual receptor quantities on the cell surface.

Thus, as an in-depth characterization of the Fc $\gamma$ R numbers on tissue-resident macrophages is lacking, we set out to quantify Fc $\gamma$ Rs on tissue-resident $M \Phi$ in the lung, liver, skin, spleen, kidney and brain. Our study identified a striking organ-specific expression pattern of Fc $\gamma$ Rs on different tissue-resident macrophage subsets, providing the basis for understanding their activity in triggering local IgG subclass-dependent effector functions. 


\section{Results}

\subsection{Identification of Organ Resident Macrophage Subsets}

A prerequisite to quantifying Fc $\gamma R$ expression on tissue-resident macrophage subsets is a reliable macrophage identification in tissue extracts of the skin, lung, liver, spleen, kidney and brain via a FACS analysis. As depicted in Figure 1, and in gating strategies provided for the different organs, most macrophage populations can be clearly identified based on the expression of selective marker subsets. However, certain organ-resident macrophage subsets, such as macrophage subsets in the lung and Kupffer cells in the liver, may be more difficult to separate, prompting us to include our gating strategies in each figure.

A

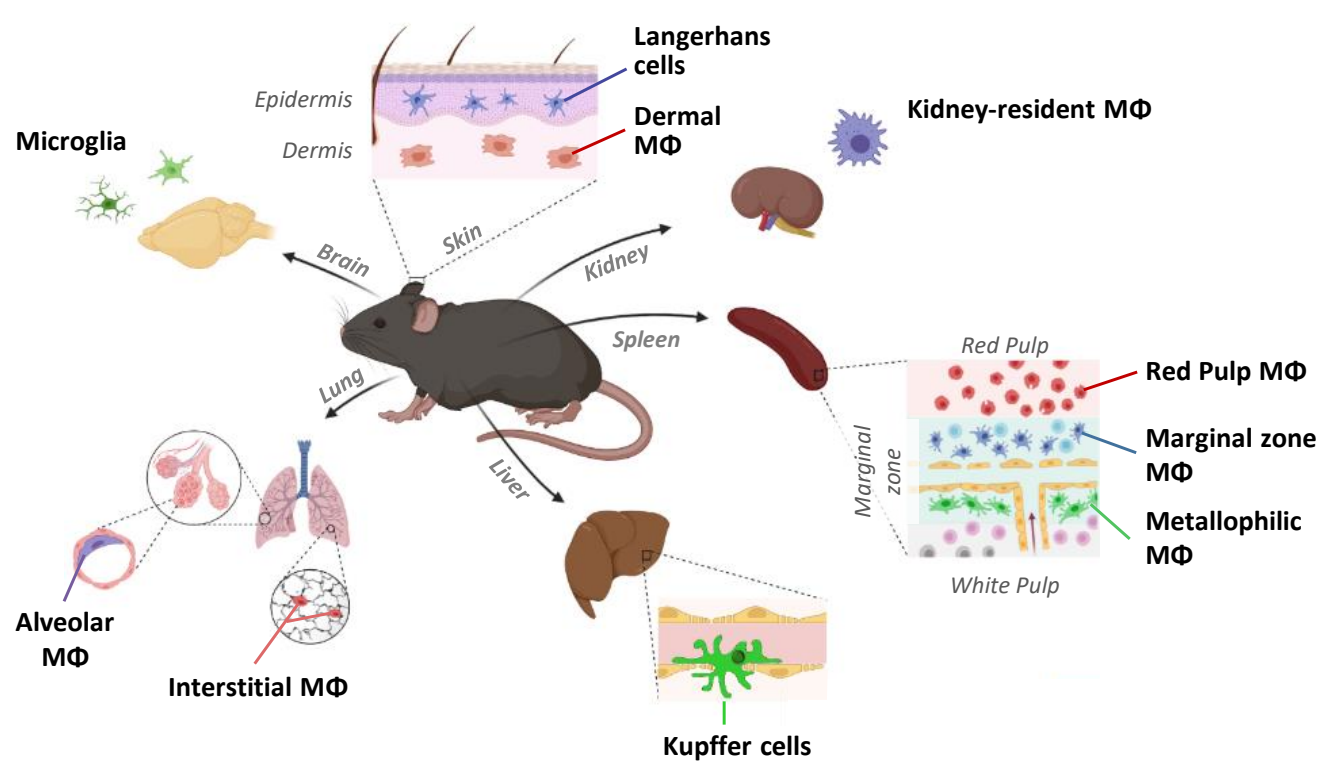

B

\begin{tabular}{|c|c|c|c|c|c|c|c|c|}
\hline $\begin{array}{l}\text { Surface } \\
\text { Marker }\end{array}$ & $\begin{array}{l}\text { Langerhans } \\
\text { cells }\end{array}$ & $\begin{array}{c}\text { MHCII CD11c } \\
\text { Dermal M } \Phi\end{array}$ & $\begin{array}{l}\mathrm{MHCll}^{+} \mathrm{CD}_{11 \mathrm{c}^{+}} \\
\text {Dermal cells }\end{array}$ & $\begin{array}{l}\text { Marker / } \\
\text { Feature }\end{array}$ & Kupffer cells & $\begin{array}{l}\text { Surface } \\
\text { Marker }\end{array}$ & Alveolar MФ & Interstitial M $\Phi$ \\
\hline CD45 & + & + & + & CD45 & low* & CD45 & + & + \\
\hline CD11b & + & ++ & ++ & CD11b & low * & CD11b & $-1+$ & + \\
\hline$F 4 / 80$ & + & + & + & $F 4 / 80$ & + & $F 4 / 80$ & + & + \\
\hline CD11c & + & - & low to + & Tim4 & + & CD11c & + & - \\
\hline MHC II & + & - & + & CD102 & - & MerTK & + & + \\
\hline Langerin & ++ & - & - & $\begin{array}{l}\text { Side scatter } \\
\text { (SSC) }\end{array}$ & low & Siglec-F & + & - \\
\hline $\begin{array}{l}\text { Surface } \\
\text { Marker }\end{array}$ & Red pulp M $\Phi$ & $\begin{array}{l}\text { Marginal } \\
\text { zone M } \Phi\end{array}$ & $\begin{array}{c}\text { Metallophilic } \\
\text { MФ }\end{array}$ & $\begin{array}{l}\text { Surface } \\
\text { Marker }\end{array}$ & $\begin{array}{l}\text { CX3CR1 } 1^{\text {high }} \\
\text { Kidney M } \Phi\end{array}$ & $\begin{array}{l}\text { Surface } \\
\text { Marker }\end{array}$ & Microglia & \\
\hline CD45 & + & + & + & CD45 & + & CD45 & low & \\
\hline CD11b & low & + & + & CD11b & + & CD11b & + & \\
\hline$F 4 / 80$ & + & - & - & $F 4 / 80$ & + & CX3CR1 & ++ & \\
\hline CD169 & - & $-/+$ & + & Ly6C & - & & & \\
\hline SIGN-R1 & - & + & - & CX3CR1 & ++ & & & \\
\hline
\end{tabular}

Figure 1. Markers allowing to identify tissue-resident macrophages subsets. (A) Schematic representation of the organs and organ-specific tissue-resident macrophages analyzed in this work, i.e., microglia from the brain; Langerhans cells from the epidermis and dermal macrophages from the dermis of the skin; kidney-resident macrophages, red pulp macrophages, the marginal zone and metallophilic macrophages from the spleen; Kupffer cells from the liver, alveolar macrophages from bronchoalveolar lavage and interstitial macrophages from tissue of the lung. (B) Depicted are the cell surface markers and cellular features of tissue-resident macrophages that were used for the identification of the respective macrophage population(s) 
by flow cytometry: no clear staining with the respective antibody; $-/+$, no clear shift upon staining with the respective antibody but "broadening" of the cell population in the corresponding dot plot; low, a distinct but minor shift upon staining with the respective antibody or low light scatter in comparison to several other cell populations; + , a distinct shift upon staining; ++, very prominent endogenous fluorescence (CX3CR1-GFP) or increase in fluorescence upon staining (Langerin, $\mathrm{CD} 11 \mathrm{~b})$ in comparison to the other cell populations and *, low staining in comparison to fluorescence minus one control but adds to the pronounced autofluorescence, resulting in a high apparent fluorescence in total.

\subsection{Impact of Organ Digestion on $F c \gamma R$ Expression}

In order to isolate cells from tissue, mechanical disintegration may be insufficient to release cells. Thus, many groups have established protocols using enzymatic tissue digestion to increase the amount of tissue-resident immune cells. These protocols often include proteases for or the disruption of connective tissue components, which might affect the proteins on the cell membrane, including Fc $\gamma$ Rs. Thus, we first set out to verify that immune cell preparation by tissue digestion does not significantly affect the Fc $\gamma$ receptor expression (Figure 2). We compared the Fc $\gamma$ R expression on alveolar macrophages (AM) isolated either by bronchoalveolar lavage or by lung tissue digestion. As shown in Figure $2 \mathrm{~A}$, neither cell isolation protocol resulted in major differences in $\mathrm{Fc} \gamma \mathrm{R}$ expression. In a further control experiment, we incubated leukocytes from the peripheral blood with the enzyme mix used for tissue disruption and again compared the Fc $\gamma \mathrm{R}$ expression to untreated cells. As shown in Figure 2B, no major effect of the Fc $\gamma R$ expression on the different cell subsets was noted, suggesting that the enzyme mix used for tissue-resident macrophage isolation does not affect the cellular Fc $\gamma$ R expression. Moreover, we established reference curves for each Fc $\gamma R$ to allow a quantification of the Fc $\gamma R$ numbers or antibodybinding sites for $\mathrm{F} c \gamma \mathrm{R}$-specific antibodies (exemplarily shown for a quantification of Fc $\gamma \mathrm{RI}$ in Figure 2C).

A

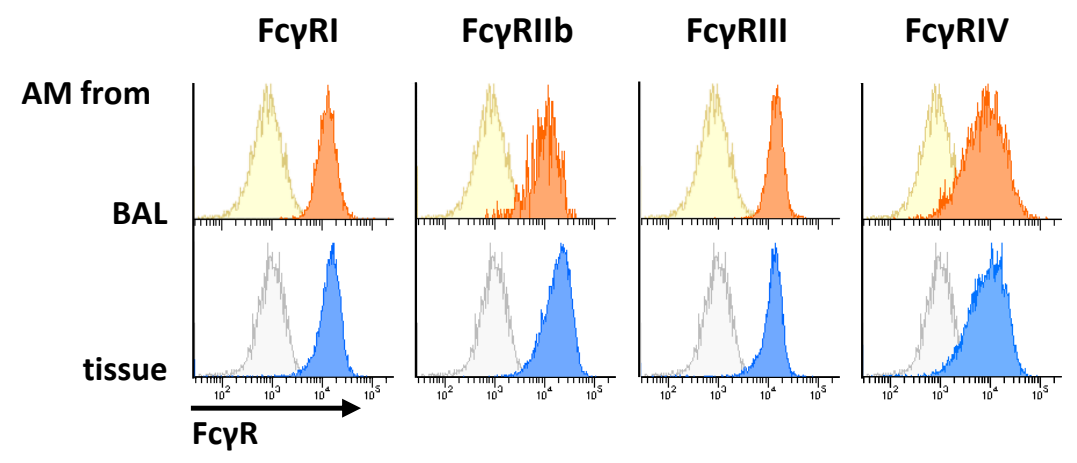

B

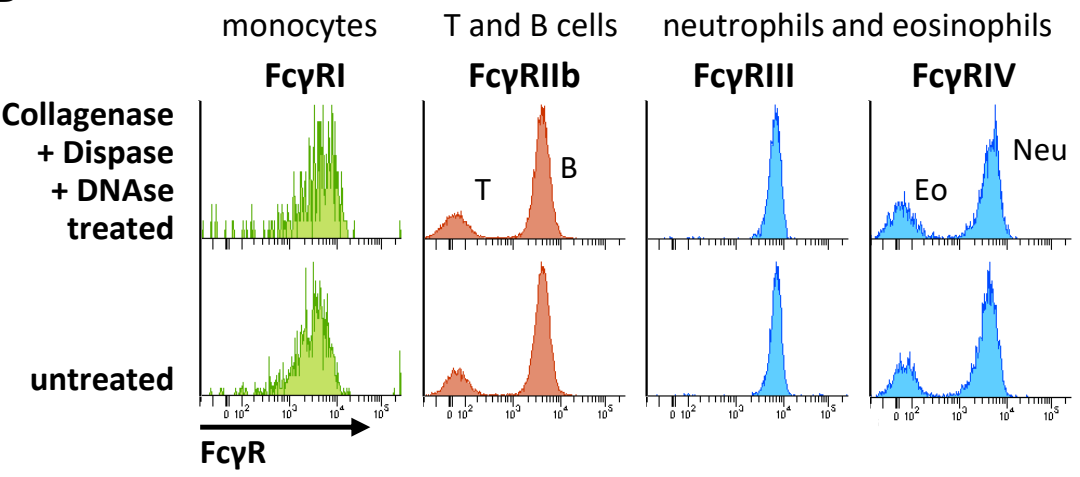

Figure 2. Cont. 


\section{C}
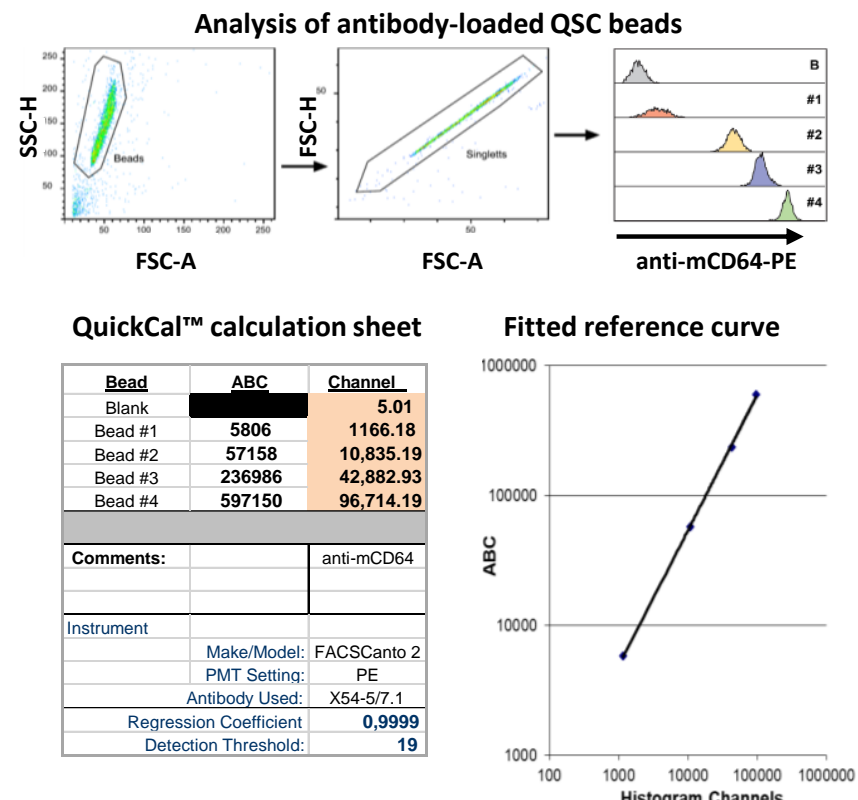

Figure 2. Impact of enzymatic digestions on $\mathrm{Fc} \gamma \mathrm{R}$ expression analysis. (A) Depicted are the flow cytometric analyses of alveolar macrophages isolated by BAL (upper panels) or in enzymatically digested lung tissue (lower panels). Fluorescence intensities are shown for a respective FMO control (light ocher and light-blue histograms) or for cells stained with PE-conjugated antibodies directed against the indicated Fc $\gamma$ Rs. X-axis scaling for the BAL samples is identical to the depicted scaling of the tissue samples (B) Histograms showing the fluorescence intensities of the indicated murine peripheral blood leukocytes upon staining with PE-conjugated antibodies that are specific for the indicated Fc $\gamma$ Rs. The blood samples have been incubated without enzymes (lower panels) or with collagenase D, Dispase ${ }^{\circledR}$ and DNase I (upper panels) prior to antibody staining. X-axis scaling for the enzymatically treated samples is identical to the depicted scaling of the untreated samples. (C) Depicted is - as an example - the establishment of an anti-CD64 (Fc $\gamma$ RI) reference curve for the deduction of the number of anti-Fc $\gamma$ R-binding sites presented as the antibody-binding capacity (ABC) from the median fluorescence intensity. Five different types of QSC beads with known anti-mouse IgG-binding sites were loaded with an anti-Fc $\gamma$ R antibody and analyzed by flow cytometry. Aggregated beads were excluded, and the fluorescence intensity of each single bead population was measured (upper panel). In the lower left panel, an excerpt from a QuickCal ${ }^{\mathrm{TM}}$ calculation sheet is shown, in which the detection threshold and quality of fitting (represented by the regression coefficient) are calculated from the known ABC values of the beads and measured fluorescence intensity ("channel"). The lower right panel depicts the reference curve for CD64 fitted to the anti-CD64-binding capacity (ABC) vs. fluorescence intensity (histogram channels) of the reference beads.

\subsection{FcrR Quantification on Lung Macrophage Subpopulations}

In the lung, alveolar macrophages (AM) could be clearly identified as Siglec Figh $\mathrm{CD} 11 \mathrm{c}^{\text {high }}$ cells as the most prominent myeloid population in the bronchoalveolar lavage (Figure 3A). Apart from AM, interstitial macrophages (IM) are the other major macrophage subset in the lung and are characterized by the expression of MerTK, CD11b and CD64 and the absence of Siglec F (reviewed in Reference [51]). To identify IM, we followed the strategy of Gibbings et al. [52] by gating on MerTK- and CD64-positive cells from enzymatically digested lung cell preparations, followed by the distinction between AM and $\mathrm{IM}$ via CD11c and CD11b (Figure 3B). However, for an accurate quantification of the Fc $\gamma \mathrm{R}$ numbers, a gating strategy identifying IM without CD64 is critical, as a fluorescence minus one (FMO) control is indispensable to correct for the relatively strong autofluorescence of certain macrophage subsets. To achieve this, we analyzed IM identified in a CD64stained sample for other pairs of markers (CD11b vs. CD45, Siglec F vs. CD11c and F4/80 vs. MerTK) and their light scatter characteristics to allow a CD64-independent IM 
identification (Figure 3B). Based on the location of IM in these dot plots, we defined four corresponding gates. Applying the combination of these four gates on the single viable lineage ${ }^{-/ \text {low }}$ cells clearly identified a MerTK ${ }^{+} \mathrm{CD} 64^{+}$population and, thus, could be used for IM identification without staining for CD64.

A
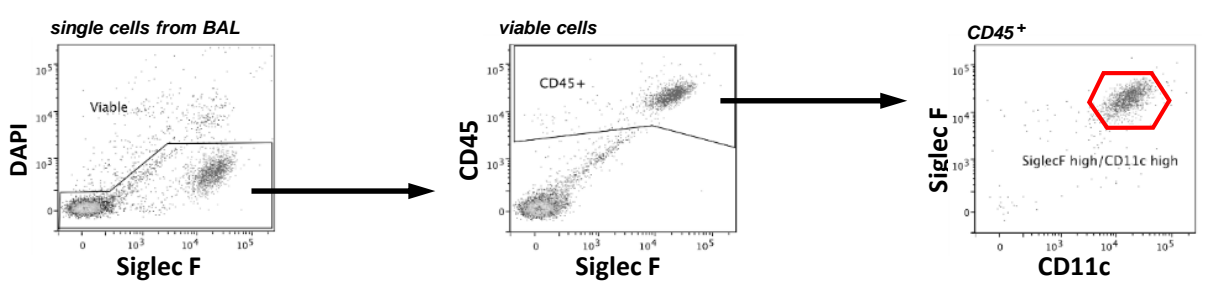

B
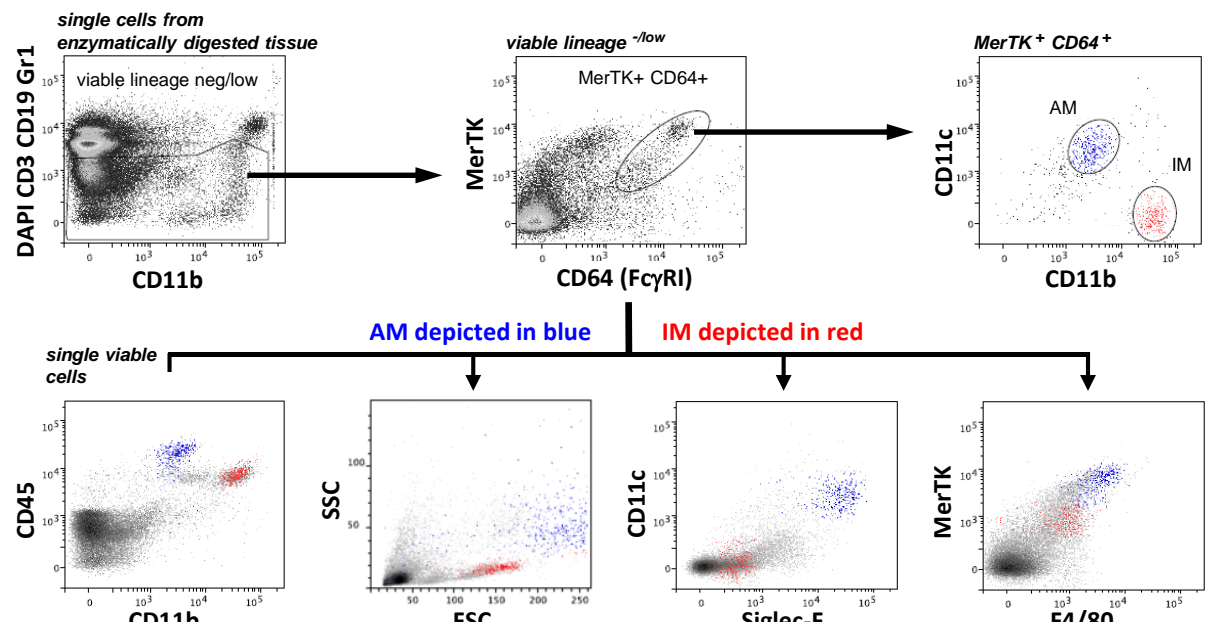

AM depicted in blue

IM depicted in red
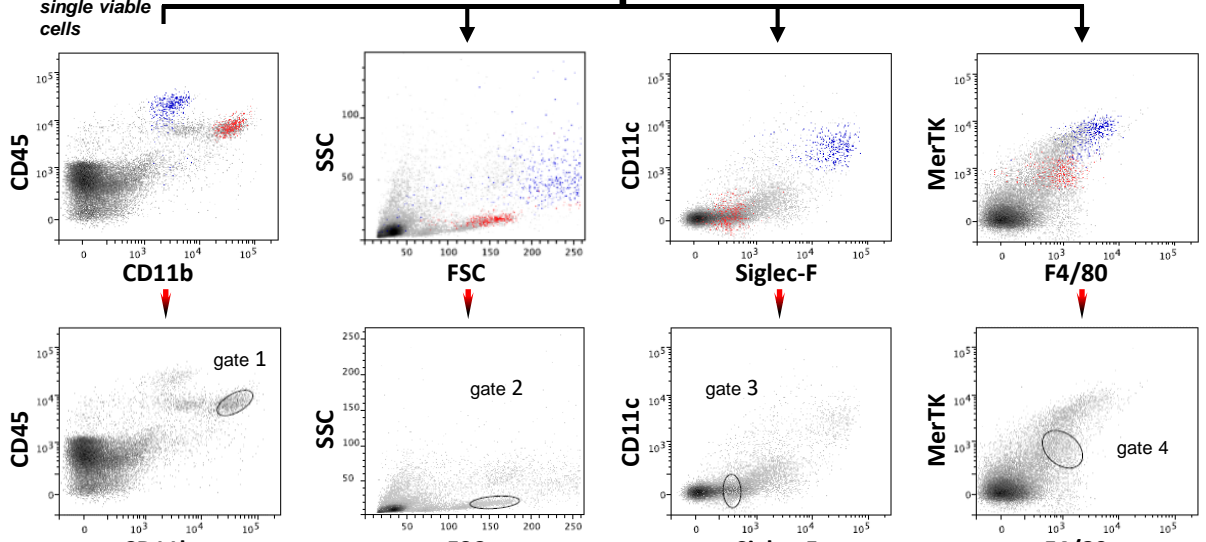

1

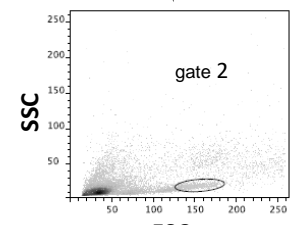

$\checkmark$

CD11
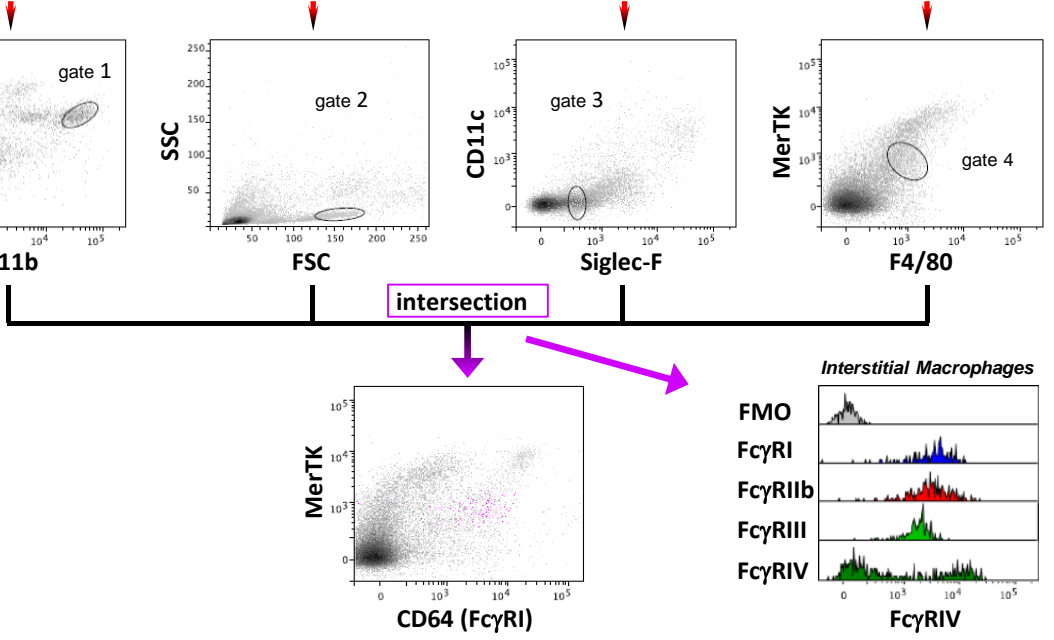

$\mathrm{F} 4 / 80$

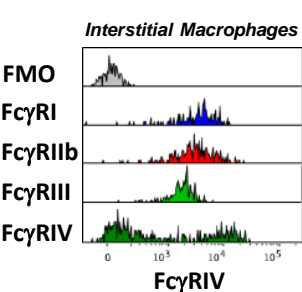

C

Alveolar Macrophages

Interstitial Macrophages
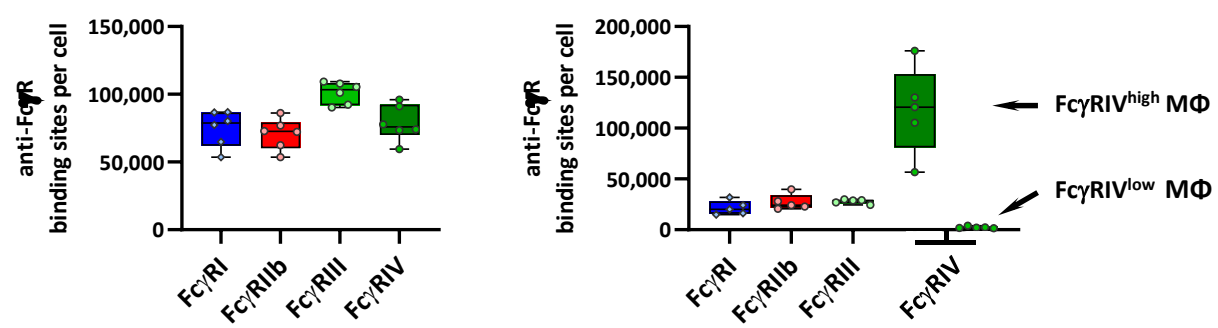

Figure 3. Characterization of the Fc $\gamma R$ expression on pulmonary macrophages. (A) Depicted are single cells from the bronchoalveolar lavage (BAL). By selecting DAPI-negative cells, dead cell exclusion was performed. Next, the viable cells 
were subdivided based on their expression of CD45, Siglec F and CD11c. Among the CD45-positive populations, alveolar macrophages were identified by a pronounced expression of both Siglec F and CD11c. (B) Single cells from enzymatically digested lung tissue were stained with DAPI and antibodies specific for B-cell (CD19) and T-cell (CD3) markers, as well as Gr-1 (Ly6G and Ly6C) in a dump channel. Viable and CD19/CD3-negative cells and CD11b-positive Gr-1-negative-to-low cells were analyzed further to identify the macrophages as MerTK ${ }^{+} \mathrm{CD}^{+} 4^{+}$cells. The IM were characterized as CD11b high $\mathrm{CD} 11 \mathrm{c}^{-/ \text {low }}$, shown in red, and $\mathrm{AM}$ as $\mathrm{CD} 11 \mathrm{~b}^{\text {low }} \mathrm{CD} 11 \mathrm{c}^{\text {high }}$ in blue for comparison (upper panels). The IM and AM are marked in red and blue in dot plots for the various combinations of markers (second row of panels). The gates were set to identify IM in these dot plots (third row of panels). The intersection of these gates, depicted in magenta, was used to define a population that corresponds to the $\mathrm{CD}^{+} 4^{+} \mathrm{MerTK}^{+} \mathrm{IM}$ in the anti-CD64-stained sample (lower panel). (C) Depicted are the number of anti-Fc $\gamma \mathrm{R}$-binding sites per cell as a quantitative correlate of the Fc $\gamma \mathrm{R}$ receptor expression. Data are presented as box plots showing the median and interquartile range and whiskers showing extremes together with all single values. $n=6$ for AM and 5 for IM.

Using this gating strategy, the quantification of Fc $\gamma \mathrm{R}$ numbers or, more accurately, the Fc $\gamma$ R-specific antibody-binding capacity (ABC; represented as antibody-binding sites/cell) on the pulmonary $\mathrm{M} \Phi$ subsets demonstrated a pronounced heterogeneity with respect to the Fc $\gamma$ R numbers. Whereas AM showed a strong expression of all four Fc $\gamma$ Rs at 75,000$100,000 \mathrm{ABC}$, with Fc $\gamma \mathrm{RIII}$ being expressed at the highest level, the IM expressed Fc $\gamma \mathrm{RI}$, IIb and III at much lower levels (roughly at 25,000 ABC). Of note, whereas the IM population showed a homogenous expression for Fc $\gamma \mathrm{RI}$, Ilb and III, it revealed two subpopulations with either a very high $(120,000 \mathrm{ABC})$ or very low/absent Fc $\gamma$ RIV expression (Table 1 and Figure 3C), consistent with the previous identification of several subsets of IM being present in the lung [52].

\subsection{Fc $\gamma R$ Quantification on Splenic Macrophage Subsets}

The spleen represents another organ that contains numerous subsets of organ-resident macrophages, including red pulp macrophages (RPM) and several marginal zone macrophage subsets. RPM were identified by low-to-moderate CD11b and F4/80 expression, whereas the macrophages in the marginal zone lacked F4/80 but expressed CD169 (metallophilic macrophages) or SIGNR1 (marginal zone macrophages) (Figure 4A). With respect to Fc $\gamma R$ numbers, RPM had a moderate expression of all the activating Fc $\gamma$ Rs and a low expression of the inhibitory Fc $\gamma \mathrm{RIIb}$. In contrast, macrophages located in the marginal zone only revealed a moderate expression of Fc $\gamma$ RIII (roughly 27,000 ABC) and low levels of Fc $\gamma$ RIV (9000-12,000 $\mathrm{ABC}$ ). The Fc $\gamma \mathrm{RI}$ and inhibitory Fc $\gamma \mathrm{RIIb}$ expression were even lower, with levels at around 3000 ABC (Table 1 and Figure 4B). The main difference between the RPM and marginal zone macrophages-the more pronounced expression of Fc $\gamma$ RI and RIV on the former-was verified by a fluorescence microscopic analysis of spleen sections where both receptors were clearly detectable in the red pulp but barely outside (Figure 4C). 
A
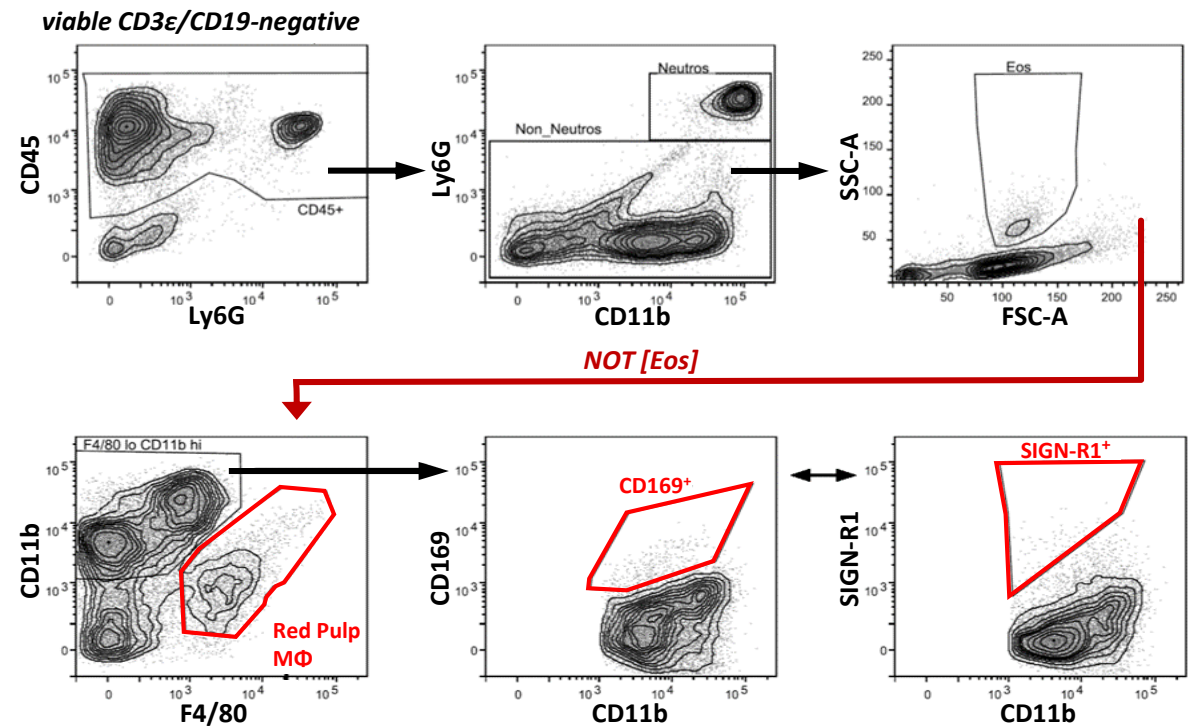

B
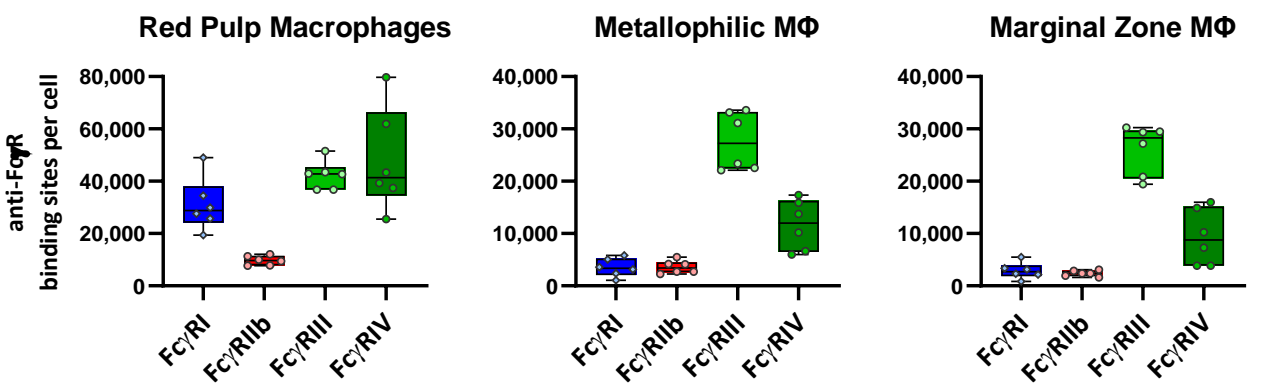

C
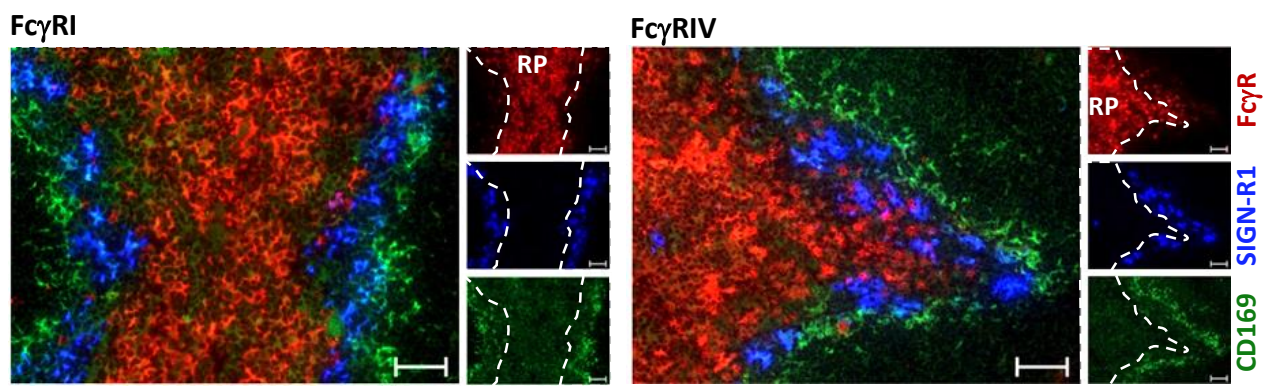

Figure 4. Characterization of the Fc $\gamma$ R expression on splenic macrophages. (A) Depicted is the gating strategy for splenic macrophages. B, T and dead cells were excluded by using a dump channel (using CD19 and CD3e and DAPI). From CD45positive leukocytes, neutrophils were excluded by Ly6G expression and eosinophils by their light scatter characteristics with high side scatter (SSC). Within the remaining leukocyte population, red pulp macrophages were characterized by low CD11b expression and pronounced F4/80 expression. Among CD11b-high cells with no or low F4/80 staining, metallophilic macrophages were characterized by the expression of CD169. Cells with a high expression of SIGN-R1 were regarded as marginal zone macrophages. (B) Shown are the number of anti-Fc $\gamma$ R-binding sites per cell as a quantitative correlate of the Fc $\gamma$ R expression on RPM, the marginal zone and metallophilic MФ. Data are presented as box plots showing the median and interquartile range and whiskers presenting extremes with all single values. $n=6$. (C) Analysis of the Fc $\gamma$ RI and RIV expression on splenic macrophages by fluorescence microscopy. Fc $\gamma$ RI (left panel) and Fc $\gamma$ RIV (right panel) are shown in red. The presence of SIGN-R1 and CD169 is indicated by blue or green, respectively. Shown is the overlay of Fc $\gamma$ R, SIGN-RI and CD169, as well as each single fluorescence channel. In the single-channel pictures, the position of the red pulp is shown based on its demarcation from the SIGN-R1-positive macrophages (dashed line). Scale bars represent $50 \mu \mathrm{m}$. 


\subsection{FcrR Quantification on Skin Resident Macrophage/DC Subsets}

In the epidermis and dermis of the skin, we differentiated between dermal macrophages $(\mathrm{DM})$ and Langerhans cells. The latter were identified as $\mathrm{CD}_{4} 5^{+} \mathrm{CD} 11 \mathrm{~b}^{+} \mathrm{F} 4 / 80^{+}$Langerin $^{+}$ in the epidermal cell preparations (Figure 5A). In the dermis, we identified two subsets of $\mathrm{CD}_{4} 5^{+} \mathrm{F} 4 / 80^{+}$Langerin ${ }^{-} \mathrm{CD} 11 \mathrm{~b}^{\text {high }}$ cells, which differed in the expression of both in MHC II and CD11C (Figure 5B). With reference to the markers used both in this work and previous publications, the $\mathrm{MHC} \mathrm{II}^{-} \mathrm{CD} 11 \mathrm{c}^{-}$subpopulation correlated very well with both the DM characterized as MHC II ${ }^{\text {low }} \mathrm{CD} 11 \mathrm{c}^{-} \mathrm{CD} 11 \mathrm{~b}^{\text {high }} \mathrm{F} 4 / 80^{+}$by Merad et al. [53] and one of the two subsets of dermal macrophages described by Tamoutounour and colleagues ("P4"; MHC II ${ }^{-}$CD11 $\mathrm{c}^{-} \mathrm{CD} 11 \mathrm{~b}^{+} \mathrm{F} \gamma \mathrm{R} \mathrm{R}^{\mathrm{high}}$ ). A microscopic analysis of the sorted MHCII ${ }^{-}$ CD11 ${ }^{-}$DM indicated that this population also contained melanophages, i.e., macrophages that have taken up melanosomes from neighboring melanocytes. The cell surface markers of the $\mathrm{MHC} \mathrm{II}{ }^{+} \mathrm{CD} 11 c^{\text {low to + }}$ subpopulation resembled-except for the extent of the CD11c expression-that of the second DM subset described by Tamoutounour et al. ("P5"; MHC $\left.\mathrm{II}^{+}, \mathrm{CD} 11 \mathrm{c}^{- \text {to low }} \mathrm{CD} 1 \mathrm{~b}^{+} \mathrm{Fc} \gamma \mathrm{RI}^{\text {high }}\right)$ [54], as well as that of the dermal Langerin-negative DCs described by Merad et al. (MHC $\mathrm{II}^{+} \mathrm{CD} 11 \mathrm{c}^{+} \mathrm{CD} 11 \mathrm{~b}^{\text {high }} \mathrm{F} 4 / 80^{+}$) [53]. On the Langerhans cells, Fc $\gamma$ R expression was restricted to roughly equal amounts (50,000 ABC) of the inhibitory Fc $\gamma$ RIIb and the activatory Fc $\gamma$ RIII. In contrast, on both subsets of CD45 $5^{+} \mathrm{F} 4 / 80^{+}$ Langerin $^{-}$CD11 $b^{\text {high }}$ cells, both activating Fc $\gamma$ RI $(30,000$ and 100,000 ABC) and Fc $\gamma$ RIII (about 150,000 ABC) were expressed at high levels, while the expression of Fc $\gamma$ RIV was lacking. Of further note, the inhibitory Fc $\gamma$ RIIb showed a very high expression on the MHC II ${ }^{+}$subpopulation of these cells $(>200,000 \mathrm{ABC}$ ) and an extremely high expression with more than $600,000 \mathrm{ABC}$ on the $\mathrm{MHC} \mathrm{II}^{-}$skin-resident macrophage subset (Table 1 and Figure 5C).

A

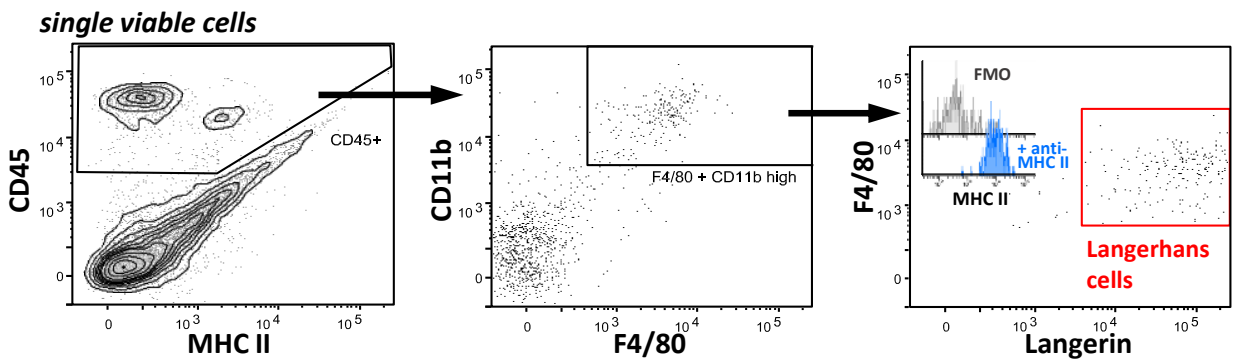

B
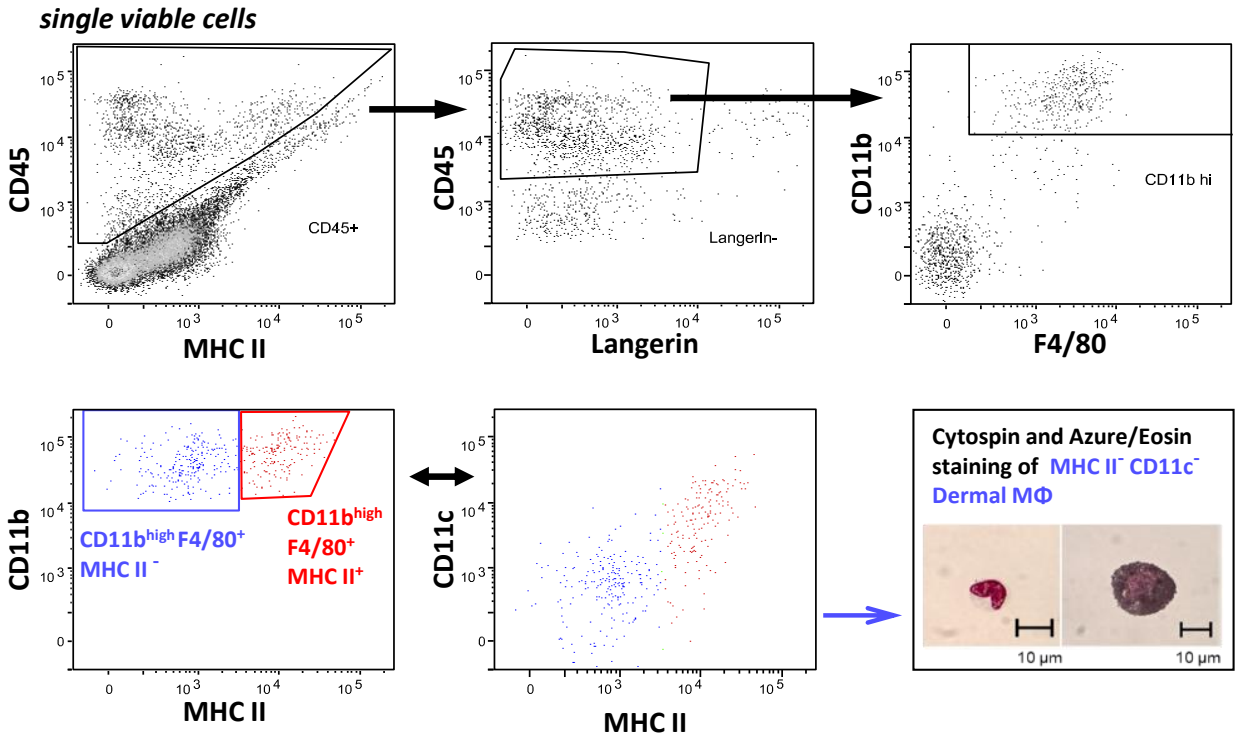

Cytospin and Azure/Eosin staining of $\mathrm{MHC} \mathrm{II}^{-} \mathrm{CD} 11 \mathrm{C}$ Dermal MФ

Figure 5. Cont. 
C

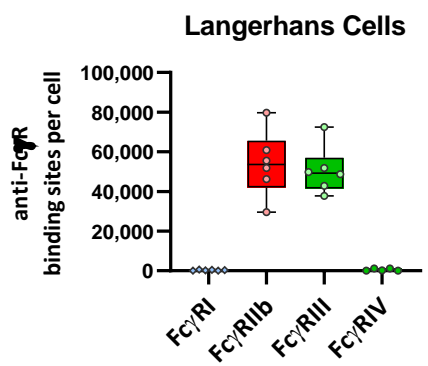

F4/80+ MHC II CD11C Dermal MФ

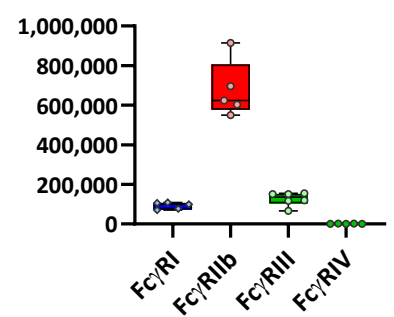

$\mathrm{F} 4 / 80^{+} \mathrm{MHC} \mathrm{II}^{+} \mathrm{CD} 11 \mathrm{c}^{+}$ Dermal Cells

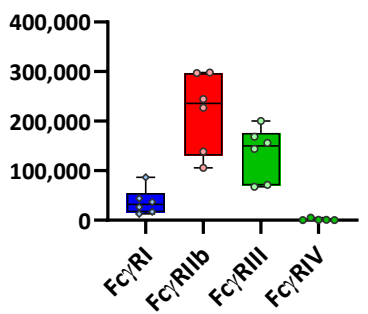

Figure 5. Characterization of the Fc $\gamma$ R expression on skin macrophage subsets. (A) Shown is the gating strategy for the identification of Langerhans cells. CD45-positive populations among single viable cells from an enzymatically digested epidermis were examined for expression of the surface markers CD11b and F4/80. Among CD11b and F4/80-doublepositive cells, Langerhans cells were identified by a pronounced expression of Langerin. The histogram inset in the right panel depicts their MHC II expression by comparing the fluorescence in the samples without (FMO, grey histogram) and with anti-MHC II antibody (blue histogram). (B) Gating strategy for Langerin-negative F4/80-positive dermal cells. Single viable cells from enzymatically digested and dermis-enriched skin were analyzed regarding their CD45 and Langerin expression to exclude Langerhans cells among the CD45-positive leukocytes. Among the CD45 ${ }^{+}$Langerin-negative cells, two subpopulations within the CD11b and F4/80-positive cells were distinguished based on a high or low level of MHC II expression (depicted in blue or red), respectively. Both population were then examined for CD11c expression. Inset: Microscopic analysis of the sorted MHC II ${ }^{-}$CD11c ${ }^{-}$DM. (C) Depicted is the ABC for each Fc $\gamma \mathrm{R}$ per cell as a quantitative correlate of the individual $\mathrm{F}_{\mathrm{c}} \gamma \mathrm{R}$ numbers. Data are presented as box plots showing the median and interquartile range and whiskers depicting extremes together with all single values. $n=6$ or 5 upon the exclusion of single outliers according to the Grubbs' test with alpha $=0.1$.

\subsection{Fc $\mathrm{R}$ Quantification on Liver Resident Macrophages}

In the liver, the major macrophage subset is Kupffer cells. Of note, however, when we stained liver the single-cell preparations for Kupffer cell markers F4/80 and Tim4 in combination with an Fc $\gamma$ RIIb-specific antibody, we found two F4/80 and Tim4-double-positive subpopulations that differed markedly with respect to Fc $\gamma$ RIIb expression (Figure 6A). Whereas $\mathrm{CD} 1^{+} \mathrm{CD}_{102}{ }^{+} \mathrm{SSC}^{\text {high }}$ cells represented a population with very high Fc $\gamma \mathrm{RIIb}$ (CD32b) expression (Figure 6A, central panel), the nonendothelial population (CD31$\mathrm{CD}_{102}{ }^{-} \mathrm{SSC}^{\mathrm{low}}$ ) moderately expressed Fc $\gamma \mathrm{RIIb}$ (right panel). In addition, we noted that their relative amount varied to a great extent in the individual preparations. Of note, liver sinusoidal endothelial cells (LSEC) are known to express high levels of Fc $\gamma$ RIIb [55]. Moreover, Lynch et al. showed that Kupffer cell preparations may contain a pronounced fraction of LSEC that mimic Kupffer cells with respect to cell surface marker expressions [56] due to a tight binding of the Kupffer cell membrane to the LSEC surface. To account for this issue, we added endothelial markers CD31 and/or CD102 to our FACS panel and found that, among the F4/80 Tim4-double-positive cells, the CD31 ${ }^{+} \mathrm{CD} 102^{+}$cells had a high side scatter (SSChigh), which reflected a high granularity/complexity and very high Fc $\gamma$ RIIb expression. In contrast, the nonendothelial CD31- ${ }^{-}$D $102^{-}$SSC $^{\text {low }}$ cells showed a moderate Fc $\gamma$ RIIb expression (Figure 6A). This is in accordance with the data from Ganesan et al. [55] and Kumar et al. [46], showing that Fc $\gamma$ RIIb expression on LSEC is much higher than on $\mathrm{KC}$. To provide further evidence that the Fc $\gamma \mathrm{RIIb}$-high subset is not a macrophage subset, we made use of BL6 Rosa26-td tomato x BL6 cx3cr1-cre mice, which express Cre recombinase under control of the cx3cr1 promoter and carry a floxed STOP cassette in front of the $t d$ tomato gene (Figure 6B). Due to the Cre-mediated excision of this STOP cassette, tdTomato is expressed in all cells that express CX3CR1 - also transiently-at any point of their development, independent of an ongoing CX3CR1 expression. Thus, all liver resident Kupffer cells should express tdTomato in these mice. Indeed, we could verify that, among the F4/80 Tim $4^{+}$cells, the SSC ${ }^{\text {high }} \mathrm{CD} 102^{+}$subpopulation lacked tdTomato expression (Figure $6 \mathrm{C}$ ). This strongly suggests that this Fc $\gamma \mathrm{RIIb}^{\text {high }}$ population is neither a myeloid cell population expressing endothelial markers nor are these cells aggregates of KC and endothelial cells. 
In fact, it seems much more likely that the $\mathrm{F} c \gamma \mathrm{RIIb}^{\text {high }} \mathrm{CD} 102^{+}$cells are a population of liver endothelial cells (i.e., LSECS) that carry markers of macrophage membranes on their surfaces. In contrast, $\mathrm{F} 4 / 80^{+} \mathrm{Tim} 4^{+} \mathrm{CD} 102^{-}$SSC $^{\text {low }}$ cells were clearly identified as tdTomato-expressing myeloid cells and represent the Kupffer cell population among $\mathrm{F} 4 / 80^{+} \mathrm{Tim} 4^{+}$cells. With respect to Fc $\gamma \mathrm{R}$ expression, the Kupffer cells expressed all three activating Fc $\gamma$ Rs, although Fc $\gamma$ RI and Fc $\gamma$ RIII were less abundant (around 20,000 ABC) than Fc $\gamma$ RIV (50,000 ABC). Similar to the marginal zone and metallophilic macrophages in the spleen, the inhibitory Fc $\gamma$ RIIb was expressed at relatively low levels (9000 ABC) (Table 1 and Figure 6E).

A

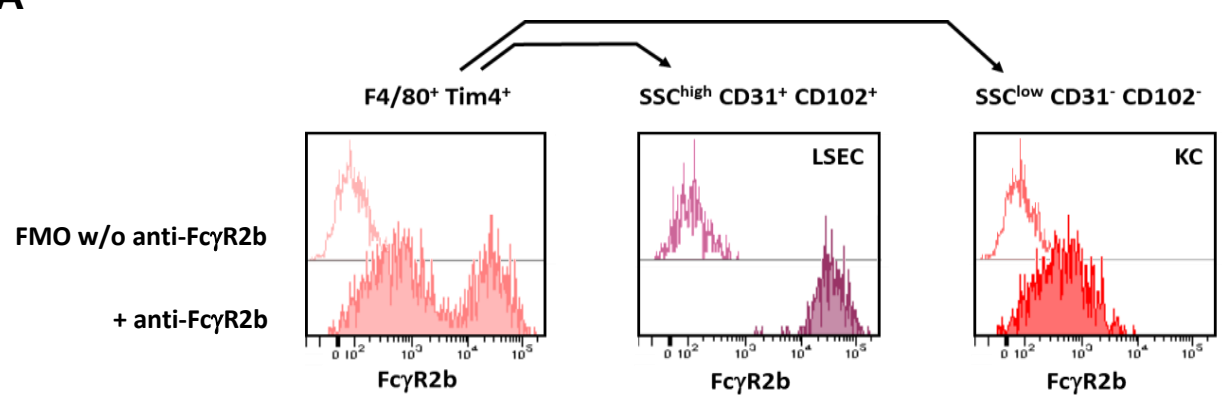

B
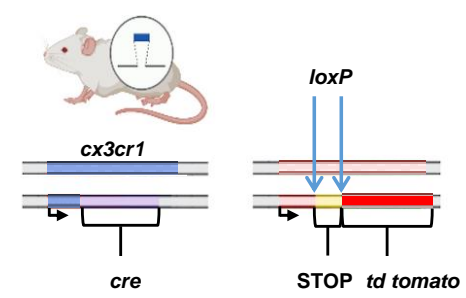

D
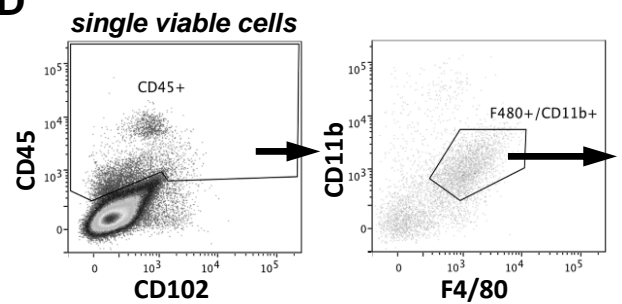

E

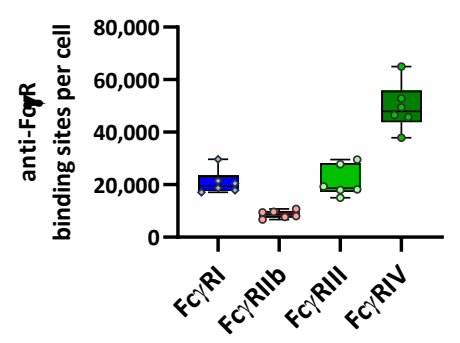

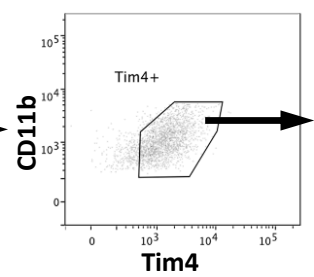

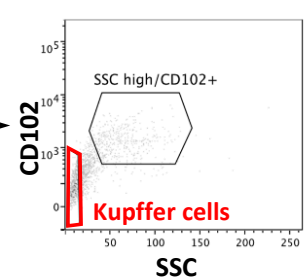

C $\mathrm{Fu}^{4} 8 \mathrm{O}^{+} \mathrm{Tim}^{+}$

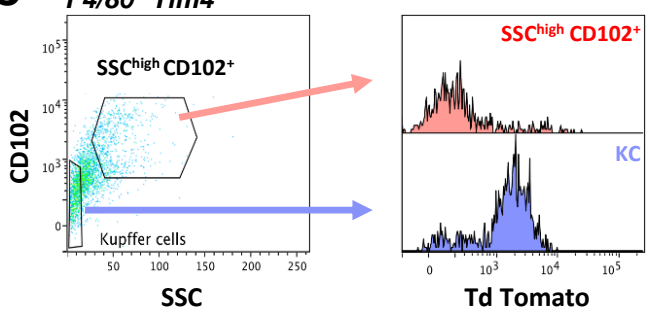

SSC

Figure 6. Characterization of Fc $\gamma R$ expression on hepatic Kupffer cells. (A) Depicted is the fluorescence of F4/80 Tim4double-positive liver cells with or without anti-Fc $\gamma$ RIIb, respectively. Among these F4/80+ $\mathrm{Tim}^{+}$cells, Fc $\gamma$ RIIb expression was analyzed in populations with either a high side scatter (SSC) and the presence of endothelial markers CD31 and CD102 (medium panel) or a low side scatter and the absence of CD31 and CD103 (right panel). (B) Genetic characteristics of BL6 Rosa26-td tomato x BL6 cx3cr1-cre mice. In these mice, one allele of the CX3CR1 locus mice encodes a Cre recombinase under 
control of the CX3CR1 promoter. In addition, one allele of the Rosa 26 locus contains a td tomato gene with a preceding floxed STOP cassette. (C) Depicted is the tdTomato expression in the F4/80+ $\mathrm{Tim}^{+}$subpopulations that were either SSC high $\mathrm{CD}_{102}{ }^{+}$or CD102-negative with a low light side scatter, which represents hepatic Kupffer cells. (D) Gating strategy for the identification of Kupffer cells. Among single viable cells from enzymatically digested liver, the CD45 $5^{+}$leukocytes were analyzed with respect to CD11b, F4/80 and Tim4 expression. Among the cells positive for all three markers, we characterized KC by their low side scatter and absence of endothelial marker CD102. (E) Depicted is the ABC for each Fc $\gamma R$ per cell as a quantitative correlate of the individual $\mathrm{F}_{c} \gamma \mathrm{R}$ numbers. Data are presented as box plots depicting the median and interquartile range and whiskers showing extremes together with all the single values; $n=6$.

\subsection{Fc $\gamma R$ Quantification on Kidney Macrophages}

In the kidney, we identified macrophages as CX3CR1-positive (by using CX3CR1-GFP reporter mice), F4/80 ${ }^{+} \mathrm{FSC}^{\text {high }}$ and ${\mathrm{Ly} 6 \mathrm{C}^{-}}^{-}$cells (Figure $\left.7 \mathrm{~A}\right)$. When analyzing the F4/80 expression and cell size of CD45 and GFP-double-positive cells, two populations were identified that were both F4/80-positive but differed prominently in cell size, as reflected by their forward light scatter characteristics (FSC: Figure 7A, right panel). The population with a larger cell size (FSC ${ }^{\text {high }}$ ) revealed a higher fluorescence with respect to GFP, as well as staining for $\mathrm{CD} 11 \mathrm{~b}, \mathrm{CD} 45$ and $\mathrm{F} 4 / 80$ and for all $\mathrm{F}_{\mathrm{C}} \gamma$ receptors upon the subsequent $\mathrm{FcR}$ expression analysis (not shown). Due to their very small size and the fact that they mirrored the antibody staining pattern of the FSC high population but with lower fluorescence intensities, we considered the CD45 ${ }^{+}$CX3CR1-GFP ${ }^{+}$CD11b ${ }^{+}$F4 $/ 80^{+}$Ly6C $^{-}$FSC $^{\text {high }}$ cells to be kidney-resident macrophages and assumed that the $\mathrm{FSC}^{\text {low }}$ population may represent subcellular particles thereof, which were not analyzed further. The quantification of Fc $\gamma$ Rs revealed that all the $\mathrm{F}_{c} \gamma \mathrm{R}$ species were expressed. Among the activating $\mathrm{F}_{\mathrm{c}} \gamma \mathrm{Rs}, \mathrm{F} c \gamma \mathrm{RIV}$ was expressed at the highest level (200,000 ABC), whereas Fc $\gamma$ RI (59,000 ABC) and Fc $\gamma$ RIII (38,000 ABC) were present at lower levels (Figure 7B and Table 1). With 95,000 ABC, the inhibitory Fc $\gamma$ RIIb was expressed at relatively high levels compared to the other organ-resident macrophage subsets (with the exception of the dermal macrophages) (Table 1).

A
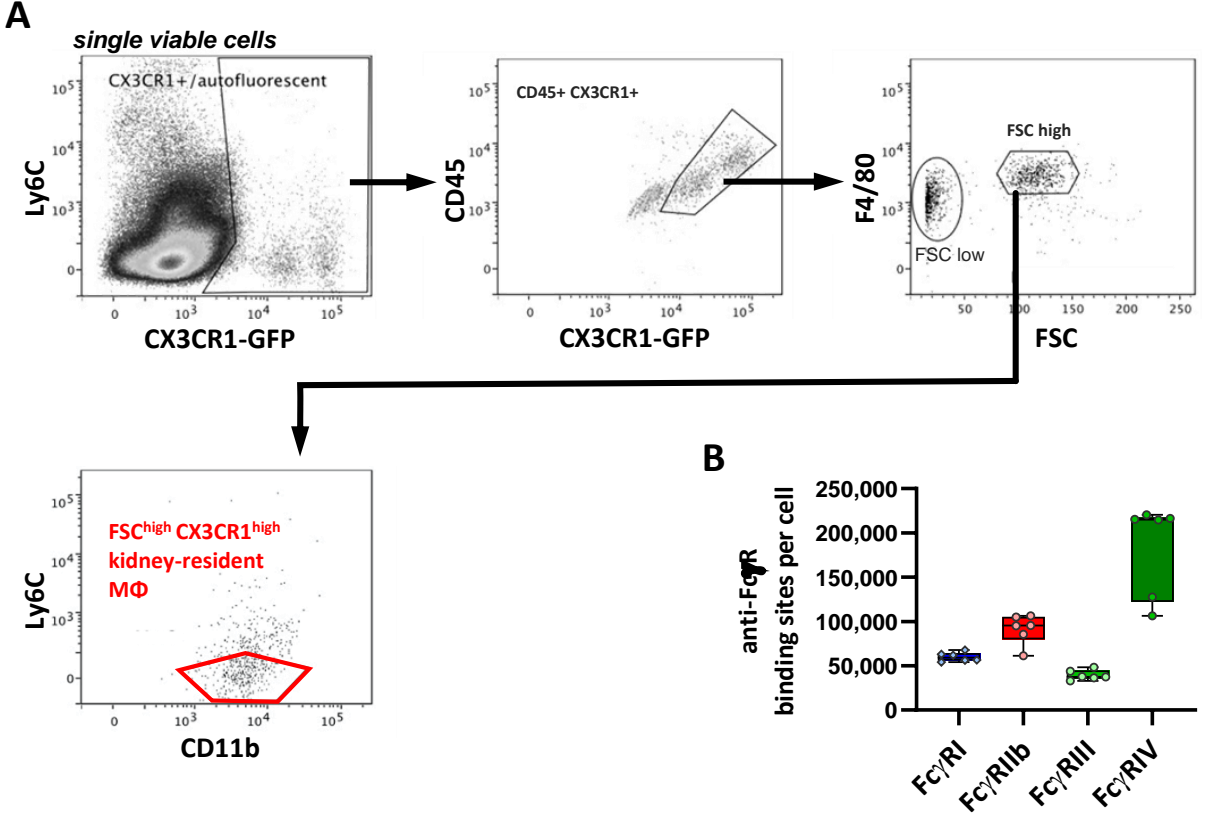

Figure 7. Characterization of $\mathrm{F}_{\mathrm{c}} \gamma \mathrm{R}$ expression on kidney-resident macrophages. (A) Gating strategy for the identification of kidney-resident $\mathrm{M} \Phi$. Single viable cells from enzymatically digested kidneys of B6 $c x 3 c r 1^{+/ 8 f p}$ mice were examined for $c x 3 r c r 1$ promoter-driven GFP and CD45 expression. CD45 ${ }^{+} \mathrm{CX} 3 \mathrm{CR} 1^{+}$cells were then analyzed with respect to $\mathrm{F} 4 / 80$ expression and cell size, as reflected by their forward light scatter characteristics (FSC). In the F4/80 ${ }^{+} \mathrm{FSC}^{\text {high }}$ population, we then selected cells that were negative for Ly6C but positive for CD11b. (B) Depicted are the number of anti-Fc $\gamma$ R-binding sites per cell as a quantitative correlate of $\mathrm{Fc} \gamma \mathrm{R}$ expression. Data are presented as box plots depicting the median and interquartile range and whiskers showing extremes together with all single values; $n=6$. 


\subsection{Fc $\gamma R$ Quantification on Brain Macrophages}

In the brain, microglia represent the predominant organ resident macrophage subset. By using CX3CR1-GFP reporter mice and CD45, we were able to clearly identify microglia in brain single-cell preparations, which revealed intermediate CD45 expression and very high $c \times 3 c r 1$-associated GFP fluorescence (Figure 8A). They also displayed a pronounced expression of CD11b (not shown). While the high-affinity Fc $\gamma$ RI and the inhibitory Fc $\gamma$ RIIb were expressed at roughly equal levels (50,000 ABC), Fc $\gamma$ RIII was much less abundant $(28,000 \mathrm{ABC})$, and $\mathrm{Fc} \gamma \mathrm{RIV}$ was expressed at very low levels during the steady state (3000 $\mathrm{ABC}$ ) (Figure $8 \mathrm{~B}$ and Table 1).

A

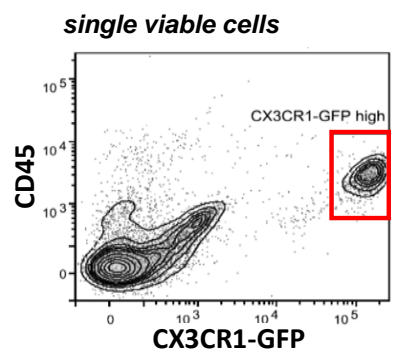

B

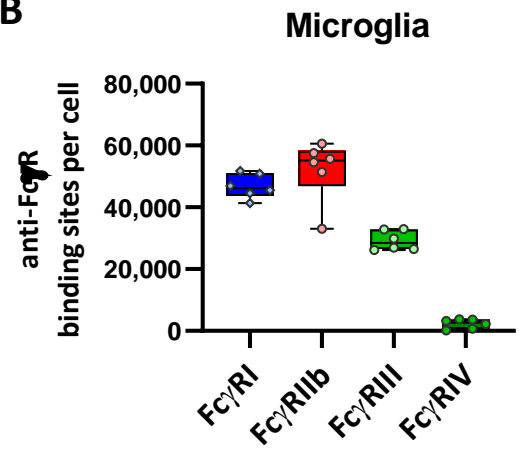

Figure 8. Characterization of $\mathrm{F}_{\mathrm{c}} \gamma \mathrm{R}$ expression on the microglia. (A) Flow cytometric characterization of microglia. Viable cells from a single cell suspension of the enzymatically digested and myelinablated brain of B6 $c x 3 c r 1^{+/ \& f p}$ mice were examined for $c x 3 r c r 1$ promoter-driven GFP expression and CD45 expression. (B) Depicted are the number of anti-Fc $\gamma$ R-binding sites per cell as the quantitative correlate of $F_{C}$ receptor expression. Data are presented as box plots depicting the median and interquartile range and whiskers showing extremes together with all single values; $n=6$.

Table 1. Expression of the Fc $\gamma$ receptors on tissue-resident macrophages.

\begin{tabular}{|c|c|c|c|c|c|}
\hline \multicolumn{2}{|c|}{ Median ABC $\left(\times 10^{3}\right.$ Binding Sites/Cell $)$} & \multirow{2}{*}{$\frac{\text { Fc } \gamma \mathbf{R I}}{20}$} & \multirow{2}{*}{$\begin{array}{c}\text { Fc } \gamma \text { RIIb } \\
9\end{array}$} & \multirow{2}{*}{$\begin{array}{c}\text { Fc } \gamma \text { RIII } \\
19\end{array}$} & \multirow{2}{*}{$\begin{array}{c}\text { Fc } \gamma \text { RIV } \\
48\end{array}$} \\
\hline & Kupffer Cells & & & & \\
\hline & Alveolar Macrophages & 79 & 73 & 103 & 76 \\
\hline & Interstitial Macrophages & 20 & 24 & 29 & $121 / 2$ * \\
\hline & Red Pulp Macrophages & 29 & 10 & 43 & 41 \\
\hline & $\begin{array}{l}\text { Metallophilic } \\
\text { Macrophages }\end{array}$ & 3 & 3 & 27 & 12 \\
\hline & $\begin{array}{c}\text { Marginal Zone } \\
\text { Macrophages }\end{array}$ & 3 & 2 & 28 & 9 \\
\hline \multirow{5}{*}{11} & Langerhans Cells & $<1$ & 54 & 49 & $<1$ \\
\hline & $\begin{array}{c}\text { MHC II }{ }^{-} \mathrm{CD}_{11 c^{-}} \\
\text {Dermal Macrophages }\end{array}$ & 99 & 624 & 135 & $<1$ \\
\hline & $\begin{array}{c}\text { MHC } \mathrm{II}^{+} \text {CD11c low to + } \\
\text { Dermal Cells }\end{array}$ & 32 & 236 & 150 & $<1$ \\
\hline & $\begin{array}{l}\text { Kidney-resident } \\
\text { Macrophages }\end{array}$ & 59 & 95 & 38 & 215 \\
\hline & Microglia & 46 & 55 & 28 & 3 \\
\hline
\end{tabular}




\section{Discussion}

\subsection{Importance of $F c \gamma R$ Quantification on Tissue-Resident Macrophage Subsets}

Studies by many groups over the last decades have highlighted that organ-resident macrophages play a decisive role for tissue homeostasis and for the orchestration of tissuespecific immune responses. The notion that mostly tissue-resident macrophages and not NK cells are the major effector cell subset in mediating the cytotoxic or immunomodulatory antibody activity underscores that an in-depth understanding of Fc $\gamma$ R expression on tissueresident macrophages is of critical importance. In addition, to understand the involvement of tissue-resident macrophages as key effector cells for autoantibody-dependent inflammation or the destruction of organs, including the skin, liver, lung and kidney, also requires a thorough analysis of Fc $\gamma R$ expression on tissue-resident macrophages. As different IgG subclasses show different affinities for individual activating and inhibitory Fc $\gamma R$, knowledge about the actual number of individual $\mathrm{Fc}_{\mathrm{c}} \mathrm{Rs}$ present on organ-resident macrophages also allows the mathematical modeling of (auto)antibody activity and, hence, may allow to predict therapeutic, antiviral and autoantibody activity in the future [41]. To provide this lacking set of data, we quantified Fc $\gamma$ R expression on organ-resident macrophages of the skin, lung, liver, kidney, brain and spleen of mice. Our study emphasizes that both the expression pattern, as well as the actual number of Fc $\gamma$ Rs present on the surface of different organ-resident macrophages, differ dramatically.

More importantly, our set of data is in line with many results obtained in different in vivo model systems of (auto)antibody activity.

For example, with respect to the activity of antitumor antibodies targeting liverresident tumor cells, it was suggested that Kupffer cells and Fc $\gamma$ RIV in combination with Fc $\gamma$ RI play a crucial role in the activity of the cytotoxic antibody [57]. Indeed, our results demonstrate that Fc $\gamma$ RIV with about 50,000 ABC is the most abundant Fc $\gamma$ R on Kupffer cells. In combination with a low level of the inhibitory Fc $\gamma$ RIIb expression, this suggests that Kupffer cells may be very efficient in taking up opsonized materials from the blood. Evidence along these lines has been provided by studies demonstrating that $\mathrm{KC}$ play an important role in the Fc $\gamma$ R-mediated clearance of circulating antigen-antibody conjugates or larger immune complexes (see, e.g., Reference [58]) or by intravital imaging studies showing that KC participate in the depletion of opsonized peripheral blood B cells in the liver [7]. In addition, the autoantibody-mediated removal of red blood cells by liver macrophages has been demonstrated directly via the histological detection of iron deposits in Kupffer cells in vivo [59].

Another prime example for an organ where Fc $\gamma$ Rs on macrophages are of major importance is the lungs. We showed that the antibody-dependent killing of melanoma metastasis is strictly dependent on Fc $\gamma$ RI and Fc $\gamma$ RIV $[40,60]$. A more recent study further suggested that alveolar macrophages may be key to the killing of tumor cells via ADCC in the lungs, which is in line with the high expression of both receptors on alveolar, but not on interstitial, macrophages (Table 1) [6]. Apart from tumor-specific antibodies, it was demonstrated that broadly neutralizing antibodies (bNAbs) against Hemagglutinin (HA) require $\mathrm{Fc}-\mathrm{Fc} \gamma \mathrm{R}$ interactions for the optimal protection of mice from influenza virus infection in vivo [61]. Subsequently, this protective effect of bNAbs was attributed largely to AM, and it was demonstrated that both murine and human non-neutralizing antibodies (nonNAbs) against HA are dependent on AM and require antibody-Fc $\gamma \mathrm{R}$ interactions to optimally protect mice from severe disease [62]. Moreover, the protection of mice against the influenza A virus by immune serum against the ectodomain of matrix protein 2 (M2e) depends on alveolar macrophages and Fc $\gamma$ Rs [63]. Thus, the deficiency of both Fc $\gamma$ RI and Fc $\gamma$ RIII strongly reduced the protection by anti-M2e serum (containing a range of IgG subclasses) against the influenza virus challenge. Purified anti-M2e antibodies of the IgG1 subclass were specifically dependent on functional Fc $\gamma$ RIII to confer an effective protection [63]. Along the same lines, mice in which alveolar macrophages were depleted by the nasal instillation of clodronate liposomes failed to achieve the antibody-mediated elimination of SARS-CoV [64]. 
In the skin, various lines of evidence indicate that the autoantibody-dependent skin blistering disease epidermolysis bullosa acquisita (EBA) is dependent on antibody-Fc $\gamma \mathrm{R}$ interactions (reviewed in Reference [65]). Specifically, Fc $\gamma$ RIV has been identified as the key mediator of tissue injury in antibody transfer-induced experimental EBA. Regarding the involved effector cells, it has been suggested that, besides the well-known function of neutrophils in pathogenesis, monocytes/macrophages also directly contribute to blister formations in experimental EBA [66]. As Fc $\gamma$ RIV, however, is virtually absent from dermal macrophages, it seems likely that blood-derived monocytes that can increase Fc $\gamma$ RIV expression upon activation [6] may be the key effector cells here. Interestingly, Fc $\gamma$ RIIb has recently been shown to control skin inflammation in an active model of EBA. While this effect has been mainly attributed to neutrophils as the main effector cells in EBA [67], the extremely high expression of the inhibitory receptor by DM may also suggest that DM could also be involved in modulating EBA. Indeed, apart from neutrophils, monocytes/macrophages have been suggested as additional effector cells in skin blister formations [66].

In the kidneys, CX3CR $1^{\text {high }} \mathrm{F} 4 / 80^{\text {high }}$ kidney-resident macrophages are located at the interstitium between endothelial cells of peritubular capillaries and the basement membrane. Recently, Stamatiades et al. showed that renal macrophages rapidly take up circulating immune complexes that reach the interstitium via transendothelial transport [68]. The activation of these macrophages induces inflammation, which is probably the mechanism underlying the particular susceptibility of the kidneys to developing inflammation due to circulating immune complexes. Stamatiades et al. further identified Fc $\gamma$ RIV as the key receptor for the renal macrophage response to circulating IC [68]. In a similar manner, Kaneko and colleagues demonstrated that Fc $\gamma$ RIV was critical for IC-induced kidney inflammation in a model of nephrotoxic nephritis [69]. The important role of Fc $\gamma$ RIV in antibody-dependent kidney pathology is in line with our finding that Fc $\gamma$ RIV with more than 100,000 ABC is by far the most abundant $\mathrm{F} c \gamma$ receptor on kidney-resident macrophages. In fact, Fc $\gamma$ RIV expression on kidney-resident macrophages is the highest among all the organ-resident macrophage subsets investigated in this work. Finally, the results by Chauhan et al. on the expression of Fc $\gamma$ Rs on microglia in a steady state revealed a high expression of inhibitory Fc $\gamma$ RIIb and barely any expression of Fc $\gamma$ RIV [70]. This corresponds well with our quantitative data with 55,000 ABC for Fc $\gamma$ RIIb but only 3000 $\mathrm{ABC}$ for Fc $\gamma$ RIV.

\subsection{Comparison to Fc $\gamma R$ Expression on Human Tissue Macrophage Subsets}

A recent study by Bruggeman and colleagues semiquantitatively assessed the Fc $\gamma \mathrm{R}$ expression on human ex vivo differentiated macrophages and select human tissue macrophages, including alveolar macrophages and macrophages from the spleen and liver [71]. Even though the methodology did not enable a quantification and direct comparison of the expression levels of different Fc $\gamma$ Rs, the relative expression of each receptor on cells from different tissues could be compared and revealed striking differences between the different macrophage populations. Importantly, this set of data corresponds well with several of our observations in the murine system. Thus, in humans and mice, Fc $\gamma$ RI revealed a much higher expression on alveolar macrophages than on most macrophages in the spleen (i.e., red pulp macrophages) and liver. Additionally, for murine Fc $\gamma$ RIV, we found a higher expression on AM than on Kupffer cells and red pulp macrophages, which both revealed comparable expressions. Accordingly, Bruggemann et al. found a very similar expression pattern for Fc $\gamma$ RIIIA, the human ortholog of murine Fc $\gamma$ RIV [27]. The same is true for the prominent expression of murine Fc $\gamma$ RIII and the human ortholog Fc $\gamma$ RIIA on AM. Additionally, human splenic CD169 ${ }^{+}$macrophages were found to exclusively express Fc $\gamma$ RIIa [72], in line with our finding that the murine ortholog Fc $\gamma$ RIII was the most prominently expressed Fc $\gamma$ receptor on marginal macrophages in mice, whereas Fc $\gamma$ RI and Fc $\gamma$ RIIb are largely missing. Human red pulp macrophages predominantly expressed low-affinity receptors Fc $\gamma$ RIIa and Fc $\gamma$ RIIIa, did not express inhibitory Fc $\gamma$ RIIb and had very low levels of high-affinity receptor Fc $\gamma$ RI [72]. 
Here, we found a very similar expression pattern for the mouse ortholog Fc receptors III and IV on murine RPM and low Fc $\gamma$ RIIb expression, albeit with a somewhat more prominent Fc $\gamma$ RI expression. However, there were also some differences between mice and humans, especially with respect to the inhibitory Fc $\gamma \mathrm{RIIb}$. Thus, among the macrophage populations tested by Bruggeman et al., including alveolar macrophages and macrophages from the spleen and liver, the highest expression of Fc $\gamma$ RIlb was found on Kupffer cells. In contrast, in mice, we found the most prominent expression among these macrophage populations on alveolar macrophages and a significantly lower expression on KC.

In summary, our work emphasizes the high level of diversity of $\mathrm{Fc} \gamma \mathrm{R}$ expression patterns on diverse subsets of tissue-resident macrophages during a steady state. Potential sex differences in the baseline Fc $\gamma \mathrm{R}$ expression on tissue-resident macrophages and, in particular, the question if and how this baseline expression changes during macrophage development or during tissue inflammation/repair will be interesting topics for future studies.

\section{Material and Methods}

\subsection{Mice}

Female mice at 8-14 weeks of age on C57BL/6 background were used in all the experiments. C57BL/6J mice (JAX strain 000664) were purchased from Janvier (Le GenestSaint-Isle, France). For the identification of cells that actively expressed CX3CR1, we used B6 $c x 3 c r 1^{+/ 8 f p}$ mice in which the $c x 3 c r 1$ gene was replaced by the gene encoding green fluorescent protein (GFP) on one allele. In order to identify cells that at any point of their development also transiently expressed CX3CR1, we used BL6 Rosa26-td tomato x BL6 cx3cr1-cre mice. These mice express cre recombinase under control of the $c x 3 c r 1$ promoter and have a floxed STOP cassette in front of the $t d$ tomato gene. Mice were kept in the animal facilities of Friedrich-Alexander University Erlangen-Nürnberg, Bavaria, Germany under specific pathogen-free conditions in individually ventilated cages, according to the guidelines of the National Institutes of Health and the legal requirements in Germany. Animal experiments conducted in the animal facility of the FAU were approved by the government of lower Franconia.

\subsection{Preparation of Murine Tissue Macrophages}

To isolate tissue-resident macrophages from various organs, mice were euthanized and perfused with PBS to minimize the presence of residual blood cells. After bronchoalveolar lavage for the isolation of alveolar macrophages, the lung, liver, spleen and ears were harvested from $\mathrm{C} 57 \mathrm{Bl} / 6 \mathrm{~J}$ mice. For the characterization of microglia in the brain and kidneyresident macrophages, we accordingly used $\mathrm{B} 6 c \times 3 c r 1^{+/ \& f p}$ mice to utilize the pronounced CX3CR1 expression of these cells for their identification.

The different organs/tissues were subjected to enzymatic digestion using DNase I, Collagenase D and/or Dispase ${ }^{\circledR}$, followed by organ-specific isolation protocols. These protocols are presented in the supplementary methods for each macrophage population/organ.

Finally, the cells were resuspended in cold FACS buffer containing sodium azide to inhibit changes in the surface presentation of the proteins and were processed for the flow cytometric analysis.

\subsection{Flow Cytometric Characterization of Murine Tissue Macrophages}

Single-cell suspensions were incubated for at least $10 \mathrm{~min}$ on ice with Fc block antibodies to minimize unspecific binding to Fc receptors, followed by staining with fluorochromeconjugated antibodies for at least $20 \mathrm{~min}$. For Fc-blocking, the cells were pretreated with anti-CD16/32 clone 2.4G2 to specifically block Fc $\gamma$ RIlb and III only when Fc $\gamma$ RIV was quantified. This Fc block was not used in the analysis of Fc $\gamma$ RI, since 2.4G2 may also block high-affinity receptor Fc $\gamma$ RI via its Fc part on cells where 2.4G2 antibody was bound in cis to Fc $\gamma$ RIIb/III [73]. Since we also found that medium-affinity receptor Fc $\gamma$ RIV can cause false-positive results in flow cytometry by binding to the Fc part of several rat and 
mouse IgG subclasses [74], Fc $\gamma$ RIV was blocked by clone 9E9 in all the assays where other receptors than Fc $\gamma$ RIV were to be analyzed.

The antibodies used for the identification of the macrophage populations are listed in Supplementary Table S1.

A common initial gating step prior to the specific gatings depicted in Figures 3-8 was the exclusion of the cell aggregates based on their light scatter characteristics by plotting the amplitude of the forward light scatter (FSC-H) against the corresponding area under

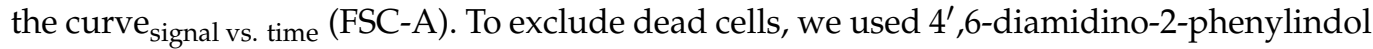
(DAPI), which penetrates dead cells much more easily than viable cells and is highly fluorescent upon intercalation into DNA. The presence of autofluorescent particles like debris and distinct cells causes "tailing" and the diagonal appearance of the respective poulations of the events in dot plots. This has to be taken into account upon the gating of cell populations and often requires the usage of polygonal gates rather than the simple distinction between "positive" and "negative" events based on a single threshold value.

Since pronounced autofluorescence is not unusual among macrophages, the apparent fluorescence for any antigen stained by fluorescent antibodies may be caused by specific antibody binding or by autofluorescence or a combination of both. To rule out the possibility that the observed apparent expression of a critical marker is due to autofluorescence, we propose that fluorescence minus one (FMO) controls be performed for each marker that is critical for identifying the distinct macrophage populations. For FMO, the control cells are stained with the respective panel of antibodies for the identification of a particular cell population, except the one directed against the antigen of interest. Here, we did this in pretests for important markers like, e.g., Langerin, F4/80, MerTK and MHC-II.

\subsection{Bright Field Microscopy}

For the light microscopic characterization of their morphology, some cell populations were sorted according to their flow cytometric characteristics described above using a FACSAria III cell sorter (BD Biosciences, Heidelberg, Germany). Subsequently, the cells were mounted on microscope slides by CytoSpin centrifugation (Cellspin I, Tharmac $\mathrm{GmbH}$, Waldsoms, Germany) and stained with a Hemacolor ${ }^{\circledR}$ Azur/Eosin kit (SigmaAldrich/ Merck KGaA, Darmstadt, Germany) prior to analysis with a Axio Observers 7 inverted microscope (Carl Zeiss Microscopy GmbH, Oberkochen, Germany).

\subsection{Fluorescence Microscopy}

To characterize the tissue location and receptor expression of spleen macrophages, the spleen was excised from perfused mice, embedded in the TissueTec O.C.T. compound (Sakura Finetek Germany GmbH, Umkirch, Germany) and frozen on dry ice. Samples were cut into 5- $\mu \mathrm{m}$ sections using a Microm HM550 cryostat (Thermo Fisher Scientific Germany, Braunschweig, Germany), and the sections were fixed with acetone and dried. Prior to staining, the sections were blocked with 5\% goat serum in PBS for $30 \mathrm{~min}$ at room temperature and then stained with antibodies against the indicated antigens for $60 \mathrm{~min}$ at RT. Fluorescence microscopy of the stained samples was performed with an Axio Observers 7 inverted microscope.

\subsection{Quantification of Fc $\gamma$ Receptors}

Quantification of the Fc $\gamma$ receptors was carried out as described in Reference [42]. Briefly, the antibody-binding capacities (ABC) for antibodies against the respective Fc $\gamma$ receptors were calculated using reference curves that correlated with the median fluorescence intensity (MFI) of a cell population upon binding by the respective fluorochromeconjugated anti-Fc $\gamma R$ antibody, with the antibody-binding capacity (ABC) represented as the "number of antibody-binding sites/cell". These curves were generated using commercially available Quantum Simply Cellular (QSC) microspheres (Bangs Laboratories Ltd., Fishers, IN, USA), with a known numbers of antibody-binding sites as provided by the manufacturer. Beads and cells were stained with the same concentrations of the 
respective anti-Fc $\gamma R$ antibodies, using concentrations that saturated the specific antibodies binding to both cells and beads as completely as possible. The following PE-conjugated anti-Fc $\gamma \mathrm{R}$ antibodies were used for mouse receptor quantification: anti-msFc $\gamma \mathrm{RI} / \mathrm{CD} 64$ mouse IgG1 clone X54-5/7.1, anti-msFc $\gamma \mathrm{RIIb} / \mathrm{CD} 32 \mathrm{~b}$ mouse IgG2a clone AT130.2, anti$\mathrm{msF} \gamma \mathrm{RIII} / \mathrm{CD} 16$ rat IgG2a clone 275003 and anti-msFc $\gamma$ RIV Arm. hamster IgG clone 9E9 (see, also, Supplementary Table S1).

We used a single type of fluorophore-Phycoerythrin (PE) - to minimize the potential systematic variations in the quantification of different receptors by the engagement of different fluorophores. PE was chosen, since, due to its high molecular weight, typically only a single fluorochrome molecule is conjugated to each antibody, thereby minimizing the variations in a specific fluorescence. In addition, PE lacks the pronounced self-quenching capacity of fluorochromes like FITC [75].

According to the host species of the respective anti-Fc $\gamma \mathrm{R}$ antibody, anti-mouse IgG or anti-rat IgG-specific QSC beads were used following the manufacturer's instructions. Since anti-Fc $\gamma$ RIV is derived from the Armenian hamster, for which no QSC beads are available, anti-mouse IgG beads were precoated with mouse anti-hamster antibody (see the description in Reference [42]). To be able to subtract the $A B C$ background values corresponding to the background fluorescence of the respective cells, we used "fluorescence minus one" (FMO) controls in each experiment. Therefore, the cells were stained with a respective panel of antibodies for the identification of that particular cell population, except anti-Fc $\gamma \mathrm{R}$ antibodies. Of note, due to the use and quantification of the FMO controls, pronounced autofluorescence of macrophages is also not problematic for receptor quantification, as it is present in both FMO and anti-Fc $\gamma$ R-stained samples and is thus included in the subtracted $A B C$ background values.

The flow cytometric analysis was performed on FACS Canto II (BD Biosciences).

An example for the quantification procedure from the flow cytometric analysis of the reference beads to the generation of the reference curve for the calculation of the $\mathrm{ABC}$ from the MFI is provided in Figure 2C.

For the analysis of the macrophages from the skin, liver, lung and spleen, each single B6 mouse was used and analyzed in an independent experiment in one day. For the analysis of the microglia and kidney-resident macrophages, groups of two mice were analyzed per day independent from the others. The reference curves were newly prepared for two groups of mice, respectively.

\subsection{Software}

The flow cytometric data were analyzed with FACSDiva V6 (BD Biosciences) and Flowlogic (Miltenyi Biotec, Bergisch-Gladbach, Germany). QuickCal ${ }^{\circledR}$ software, provided by Bangs Laboratories Ltd., was used for the $A B C$ calculations. The figures were created using PRISM V9.2 (GraphPad Software, San Diego, CA, USA) and BioRender.com. ZEN software (Carl Zeiss AG, Oberkochen, Germany) was used for the bright field and fluorescence microscopy.

Supplementary Materials: The following are available online at https://www.mdpi.com/article/10 $.3390 /$ ijms222212172/s1.

Author Contributions: C.V., N.F. and M.B. performed the experiments and analyzed the data. M.B. conceptualized the work and supervised the experiments. M.B., C.V., N.F. and F.N. interpreted the data. M.B. and F.N. wrote the manuscript. All authors have read and agreed to the published version of the manuscript.

Funding: This research was funded by the GERMAN RESEARCH FOUNDATION (grant numbers TRR305-B02 and CRC1181-A07) and by the NIH (grant numbers U19 CETR, 5U19AI142790-02 and 1U01AI148119-01) to FN.

Institutional Review Board Statement: Mice were kept and handled according to the guidelines of the National Institutes of Health and the legal requirements in Germany. All animal experiments 
were conducted in the animal facility of the FAU and were approved by the Government of Lower Franconia. File reference TS-18/2021 Genetik.

Data Availability Statement: The individual ABC values presented in this study are openly available in FigShare at doi 10.6084/m9.figshare.16961161.

Acknowledgments: The authors thank Heike Albert for the expert technical assistance. The authors are grateful to G. Krönke for kindly providing BL6 Rosa26-td tomato x BL6 cx3cr1-cre mice.

Conflicts of Interest: The authors declare that they have no competing interests.

\section{References}

1. Hirayama, D.; Iida, T.; Nakase, H. The phagocytic function of macrophage-enforcing innate immunity and tissue homeostasis. Int. J. Mol. Sci. 2018, 19, 92. [CrossRef] [PubMed]

2. Watanabe, S.; Alexander, M.; Misharin, A.V.; Budinger, G.R.S. The role of macrophages in the resolution of inflammation. J. Clin. Investig. 2019, 129, 2619-2628. [CrossRef]

3. Hine, A.M.; Loke, P. Intestinal Macrophages in Resolving Inflammation. J. Immunol. 2019, 203, 593-599. [CrossRef]

4. Anfray, C.; Ummarino, A.; Andón, F.T.; Allavena, P. Current Strategies to Target Tumor-Associated-Macrophages to Improve Anti-Tumor Immune Responses. Cells 2019, 9, 46. [CrossRef] [PubMed]

5. Jaiswal, S.; Chao, M.P.; Majeti, R.; Weissman, I.L. Macrophages as mediators of tumor immunosurveillance. Trends Immunol. 2010, 31, 212-219. [CrossRef]

6. Lehmann, B.; Biburger, M.; Brückner, C.; Ipsen-Escobedo, A.; Gordan, S.; Lehmann, C.; Voehringer, D.; Winkler, T.; Schaft, N.; Dudziak, D.; et al. Tumor location determines tissue-specific recruitment of tumor-associated macrophages and antibodydependent immunotherapy response. Sci. Immunol. 2017, 2, eaah6413. [CrossRef]

7. Montalvao, F.; Garcia, Z.; Celli, S.; Breart, B.; Deguine, J.; Van Rooijen, N.; Bousso, P. The mechanism of anti-CD20-mediated B cell depletion revealed by intravital imaging. J. Clin. Investig. 2013, 123, 5098-5103. [CrossRef] [PubMed]

8. Krenkel, O.; Tacke, F. Liver macrophages in tissue homeostasis and disease. Nat. Rev. Immunol. 2017, 17, 306-321. [CrossRef]

9. Allard, B.; Panariti, A.; Martin, J.G. Alveolar Macrophages in the Resolution of Inflammation, Tissue Repair, and Tolerance to Infection. Front. Immunol. 2018, 9, 1777. [CrossRef] [PubMed]

10. Mosser, D.M.; Hamidzadeh, K.; Goncalves, R. Macrophages and the maintenance of homeostasis. Cell. Mol. Immunol. 2021, 18, 579-587. [CrossRef]

11. Granata, F.; Frattini, A.; Loffredo, S.; Staiano, R.I.; Petraroli, A.; Ribatti, D.; Oslund, R.; Gelb, M.H.; Lambeau, G.; Marone, G.; et al. Production of Vascular Endothelial Growth Factors from Human Lung Macrophages Induced by Group IIA and Group X Secreted Phospholipases A 2 . J. Immunol. 2010, 184, 5232-5241. [CrossRef]

12. Staiano, R.I.; Loffredo, S.; Borriello, F.; Iannotti, F.A.; Piscitelli, F.; Orlando, P.; Secondo, A.; Granata, F.; Lepore, M.T.; Fiorelli, A.; et al. Human lung-resident macrophages express CB 1 and CB 2 receptors whose activation inhibits the release of angiogenic and lymphangiogenic factors. J. Leukoc. Biol. 2016, 99, 531-540. [CrossRef] [PubMed]

13. Swirski, F.K.; Nahrendorf, M. Cardioimmunology: The immune system in cardiac homeostasis and disease. Nat. Rev. Immunol. 2018, 18, 733-744. [CrossRef]

14. Ardain, A.; Marakalala, M.J.; Leslie, A. Tissue-resident innate immunity in the lung. Immunology 2020, 159, 245-256. [CrossRef]

15. Tesch, G.H. Role of macrophages in complications of Type 2 diabetes. Clin. Exp. Pharmacol. Physiol. 2007, 34, 1016-1019. [CrossRef]

16. Cassetta, L.; Pollard, J.W. Targeting macrophages: Therapeutic approaches in cancer. Nat. Rev. Drug Discov. 2018, 17, 887-904. [CrossRef] [PubMed]

17. Bogunovic, M.; Ginhoux, F.; Helft, J.; Shang, L.; Greter, M.; Liu, K.; Jakubzick, C.; Ingersoll, M.A.; Leboeuf, M.; Stanley, E.R.; et al. Origin of the Lamina Propria Dendritic Cell Networkc Access. Immunity 2009, 31, 513-525. [CrossRef] [PubMed]

18. Tamoutounour, S.; Henri, S.; Lelouard, H.; de Bovis, B.; de Haar, C.; van der Woude, C.J.; Woltman, A.M.; Reyal, Y.; Bonnet, D.; Sichien, D.; et al. CD64 distinguishes macrophages from dendritic cells in the gut and reveals the Th1-inducing role of mesenteric lymph node macrophages during colitis. Eur. J. Immunol. 2012, 42, 3150-3166. [CrossRef]

19. Ginhoux, F.; Greter, M.; Leboeuf, M.; Nandi, S.; See, P.; Gokhan, S.; Mehler, M.F.; Conway, S.J.; Ng, L.G.; Stanley, E.R.; et al. Fate mapping analysis reveals that adult microglia derive from primitive macrophages. Science 2010, 330, 841-845. [CrossRef]

20. Schulz, C.; Gomez Perdiguero, E.; Chorro, L.; Szabo-Rogers, H.; Cagnard, N.; Kierdorf, K.; Prinz, M.; Wu, B.; Jacobsen, S.E.; Pollard, J.W.; et al. A lineage of myeloid cells independent of Myb and hematopoietic stem cells. Science 2012, 336, 86-90. [CrossRef] [PubMed]

21. Hoeffel, G.; Wang, Y.; Greter, M.; See, P.; Teo, P.; Malleret, B.; Leboeuf, M.; Low, D.; Oller, G.; Almeida, F.; et al. Adult Langerhans cells derive predominantly from embryonic fetal liver monocytes with a minor contribution of yolk sac-derived macrophages. $J$. Exp. Med. 2012, 209, 1167-1181. [CrossRef]

22. Guilliams, M.; De Kleer, I.; Henri, S.; Post, S.; Vanhoutte, L.; De Prijck, S.; Deswarte, K.; Malissen, B.; Hammad, H.; Lambrecht, B.N. Alveolar macrophages develop from fetal monocytes that differentiate into long-lived cells in the first week of life via GM-CSF. J. Exp. Med. 2013, 210, 1977-1992. [CrossRef] [PubMed] 
23. Hashimoto, D.; Chow, A.; Noizat, C.; Teo, P.; Beasley, M.B.; Leboeuf, M.; Becker, C.D.; See, P.; Price, J.; Lucas, D.; et al. Tissueresident macrophages self-maintain locally throughout adult life with minimal contribution from circulating monocytes. Immunity 2013, 38, 792-804. [CrossRef] [PubMed]

24. Yona, S.; Kim, K.-W.; Wolf, Y.; Mildner, A.; Varol, D.; Breker, M.; Strauss-Ayali, D.; Viukov, S.; Guilliams, M.; Misharin, A.; et al. Fate Mapping Reveals Origins and Dynamics of Monocytes and Tissue Macrophages under Homeostasis. Immunity 2013, 38, 79-91. [CrossRef] [PubMed]

25. Zhao, Y.; Zou, W.; Du, J.; Zhao, Y. The origins and homeostasis of monocytes and tissue-resident macrophages in physiological situation. J. Cell. Physiol. 2018, 233, 6425-6439. [CrossRef] [PubMed]

26. Brandsma, A.M.; Hogarth, P.M.; Nimmerjahn, F.; Leusen, J.H.W. Clarifying the Confusion between Cytokine and Fc Receptor "Common Gamma Chain". Immunity 2016, 45, 225-226. [CrossRef]

27. Nimmerjahn, F.; Ravetch, J.V. Fcgamma receptors: Old friends and new family members. Immunity 2006, 24, 19-28. [CrossRef]

28. Hargreaves, C.E.; Rose-Zerilli, M.J.J.; Machado, L.R.; Iriyama, C.; Hollox, E.J.; Cragg, M.S.; Strefford, J.C. Fc $\gamma$ receptors: Genetic variation, function, and disease. Immunol. Rev. 2015, 268, 6-24. [CrossRef]

29. Guilliams, M.; Bruhns, P.; Saeys, Y.; Hammad, H.; Lambrecht, B.N. The function of Fc $\gamma$ receptors in dendritic cells and macrophages. Nat. Rev. Immunol. 2014, 14, 94-108. [CrossRef]

30. Joller, N.; Weber, S.S.; Muller, A.J.; Sporri, R.; Selchow, P.; Sander, P.; Hilbi, H.; Oxenius, A. Antibodies protect against intracellular bacteria by Fc receptor-mediated lysosomal targeting. Proc. Natl. Acad. Sci. USA 2010, 107, 20441-20446. [CrossRef]

31. Nimmerjahn, F.; Gordan, S.; Lux, A. Fc $\gamma$ R dependent mechanisms of cytotoxic, agonistic, and neutralizing antibody activities. Trends Immunol. 2015, 36, 325-336. [CrossRef]

32. Roghanian, A.; Hu, G.; Fraser, C.; Singh, M.; Foxall, R.B.; Meyer, M.J.; Lees, E.; Huet, H.; Glennie, M.J.; Beers, S.A.; et al. Cyclophosphamide Enhances Cancer Antibody Immunotherapy in the Resistant Bone Marrow Niche by Modulating Macrophage Fc $\gamma$ R Expression. Cancer Immunol. Res. 2019, 7, 1876-1890. [CrossRef]

33. Gordan, S.; Albert, H.; Danzer, H.; Lux, A.; Biburger, M.; Nimmerjahn, F. The Immunological Organ Environment Dictates the Molecular and Cellular Pathways of Cytotoxic Antibody Activity. Cell Rep. 2019, 29, 3033-3046. [CrossRef]

34. Gerber, J.S.; Mosser, D.M. Reversing Lipopolysaccharide Toxicity by Ligating the Macrophage Fc $\gamma$ Receptors. J. Immunol. 2001, 166, 6861-6868. [CrossRef] [PubMed]

35. Sutterwala, F.S.; Noel, G.J.; Clynes, R.; Mosser, D.M. Selective Suppression of Interleukin-12 Induction after Macrophage Receptor Ligation. J. Exp. Med. 1997, 185, 1977-1985. [CrossRef]

36. Guzman, M.G.; Vazquez, S. The Complexity of Antibody-Dependent Enhancement of Dengue Virus Infection. Viruses 2010, 2, 2649-2662. [CrossRef]

37. Wang, T.T.; Sewatanon, J.; Memoli, M.J.; Wrammert, J.; Bournazos, S.; Bhaumik, S.K.; Pinsky, B.A.; Chokephaibulkit, K.; Onlamoon, N.; Pattanapanyasat, K.; et al. IgG antibodies to dengue enhanced for Fc $\gamma$ RIIIA binding determine disease severity. Science 2017, 355, 395-398. [CrossRef] [PubMed]

38. Bournazos, S.; Vo, H.T.M.; Duong, V.; Auerswald, H.; Ly, S.; Sakuntabhai, A.; Dussart, P.; Cantaert, T.; Ravetch, J.V. Antibody fucosylation predicts disease severity in secondary dengue infection. Science 2021, 372, 1102-1105. [CrossRef] [PubMed]

39. Lux, A.; Yu, X.; Scanlan, C.N.; Nimmerjahn, F. Impact of immune complex size and glycosylation on IgG binding to human Fc $\gamma$ Rs. J. Immunol. 2013, 190, 4315-4323. [CrossRef]

40. Nimmerjahn, F.; Ravetch, J.V. Divergent Immunoglobulin G Subclass Activity Through Selective Fc Receptor Binding. Science 2005, 310, 1510-1512. [CrossRef]

41. Robinett, R.A.; Guan, N.; Lux, A.; Biburger, M.; Nimmerjahn, F.; Meyer, A.S. Dissecting Fc $\gamma$ R Regulation through a Multivalent Binding Model. Cell Syst. 2018, 7, 41-48. [CrossRef]

42. Kerntke, C.; Nimmerjahn, F.; Biburger, M. There Is (Scientific) Strength in Numbers: A Comprehensive Quantitation of Fc Gamma Receptor Numbers on Human and Murine Peripheral Blood Leukocytes. Front. Immunol. 2020, 11, 118. [CrossRef]

43. Hobday, P.M.; Auger, J.L.; Schuneman, G.R.; Haasken, S.; Verbeek, J.S.; Binstadt, B.A. Fc $\gamma$ Receptor III and Fc $\gamma$ Receptor IV on Macrophages Drive Autoimmune Valvular Carditis in Mice. Arthritis Rheumatol. 2014, 66, 852-862. [CrossRef] [PubMed]

44. Mancardi, D.A.; Iannascoli, B.; Hoos, S.; England, P.; Daëron, M.; Bruhns, P. Fc $\gamma$ RIV is a mouse IgE receptor that resembles macrophage FceRI in humans and promotes IgE-induced lung inflammation. J. Clin. Investig. 2008, 118, 3738-3750. [CrossRef]

45. Shushakova, N.; Skokowa, J.; Schulman, J.; Baumann, U.; Zwirner, J.; Schmidt, R.E.; Gessner, J.E. C5a anaphylatoxin is a major regulator of activating versus inhibitory Fc $\gamma$ Rs in immune complex-induced lung disease. J. Clin. Investig. 2002, 110, 1823-1830. [CrossRef]

46. Kumar, V.; Ali, S.R.; Konrad, S.; Zwirner, J.; Verbeek, J.S.; Schmidt, R.E.; Gessner, J.E. Cell-derived anaphylatoxins as key mediators of antibody-dependent type II autoimmunity in mice. J. Clin. Investig. 2006, 116, 512-520. [CrossRef]

47. Syed, S.N.; Konrad, S.; Wiege, K.; Nieswandt, B.; Nimmerjahn, F.; Schmidt, R.E.; Gessner, J.E. Both Fc $\gamma$ RIV and Fc $\gamma$ RIII are essential receptors mediating type II and type III autoimmune responses via FcR $\gamma$-LAT-dependent generation of C5a. Eur. J. Immunol. 2009, 39, 3343-3356. [CrossRef] [PubMed]

48. Lunnon, K.; Teeling, J.L.; Tutt, A.L.; Cragg, M.S.; Glennie, M.J.; Perry, V.H. Systemic Inflammation Modulates Fc Receptor Expression on Microglia during Chronic Neurodegeneration. J. Immunol. 2011, 186, 7215-7224. [CrossRef] [PubMed]

49. Lever, J.M.; Hull, T.D.; Boddu, R.; Pepin, M.E.; Black, L.M.; Adedoyin, O.O.; Yang, Z.; Traylor, A.M.; Jiang, Y.; Li, Z.; et al. Resident macrophages reprogram toward a developmental state after acute kidney injury. JCI Insight 2019, 4, e125503. [CrossRef] [PubMed] 
50. Suwanichkul, A.; Wenderfer, S.E. Differential expression of functional Fc-receptors and additional immune complex receptors on mouse kidney cells. Mol. Immunol. 2013, 56, 369-379. [CrossRef] [PubMed]

51. Schyns, J.; Bureau, F.; Marichal, T. Lung Interstitial Macrophages: Past, Present, and Future. J. Immunol. Res. 2018, $2018,5160794$. [CrossRef]

52. Gibbings, S.L.; Thomas, S.M.; Atif, S.M.; McCubbrey, A.L.; Desch, A.N.; Danhorn, T.; Leach, S.M.; Bratton, D.L.; Henson, P.M.; Janssen, W.J.; et al. Three Unique Interstitial Macrophages in the Murine Lung at Steady State. Am. J. Respir. Cell Mol. Biol. 2017, 57, 66-76. [CrossRef]

53. Merad, M.; Ginhoux, F.; Collin, M. Origin, homeostasis and function of Langerhans cells and other langerin-expressing dendritic cells. Nat. Rev. Immunol. 2008, 8, 935-947. [CrossRef] [PubMed]

54. Tamoutounour, S.; Guilliams, M.; MontananaSanchis, F.; Liu, H.; Terhorst, D.; Malosse, C.; Pollet, E.; Ardouin, L.; Luche, H.; Sanchez, C.; et al. Origins and functional specialization of macrophages and of conventional and monocyte-derived dendritic cells in mouse skin. Immunity 2013, 39, 925-938. [CrossRef] [PubMed]

55. Ganesan, L.P.; Kim, J.; Wu, Y.; Mohanty, S.; Phillips, G.S.; Birmingham, D.J.; Robinson, J.M.; Anderson, C.L. Fc $\gamma$ RIIb on Liver Sinusoidal Endothelium Clears Small Immune Complexes. J. Immunol. 2012, 189, 4981-4988. [CrossRef] [PubMed]

56. Lynch, R.W.; Hawley, C.A.; Pellicoro, A.; Bain, C.C.; Iredale, J.P.; Jenkins, S.J. An efficient method to isolate Kupffer cells eliminating endothelial cell contamination and selective bias. J. Leukoc. Biol. 2018, 104, 579-586. [CrossRef] [PubMed]

57. Otten, M.A.; van der Bij, G.J.; Verbeek, S.J.; Nimmerjahn, F.; Ravetch, J.V.; Beelen, R.H.J.; van de Winkel, J.G.J.; van Egmond, M. Experimental antibody therapy of liver metastases reveals functional redundancy between Fc gammaRI and Fc gammaRIV. J. Immunol. 2008, 181, 6829-6836. [CrossRef]

58. Jenne, C.N.; Kubes, P. Immune surveillance by the liver. Nat. Immunol. 2013, 14, 996-1006. [CrossRef]

59. Fossati-Jimack, L.; Ioan-Facsinay, A.; Reininger, L.; Chicheportiche, Y.; Watanabe, N.; Saito, T.; Hofhuis, F.M.A.; Gessner, J.E.; Schiller, C.; Schmidt, R.E.; et al. Markedly Different Pathogenicity of Four Immunoglobulin G Isotype-Switch Variants of an Antierythrocyte Autoantibody Is Based on Their Capacity to Interact in Vivo with the Low-Affinity Fc $\gamma$ Receptor III. J. Exp. Med. 2000, 191, 1293-1302. [CrossRef]

60. Bevaart, L.; Jansen, M.J.H.; van Vugt, M.J.; Verbeek, J.S.; van de Winkel, J.G.J.; Leusen, J.H.W. The High-Affinity IgG Receptor, Fc $\gamma$ RI, Plays a Central Role in Antibody Therapy of Experimental Melanoma. Cancer Res. 2006, 66, 1261-1264. [CrossRef]

61. DiLillo, D.J.; Palese, P.; Wilson, P.C.; Ravetch, J.V. Broadly neutralizing anti-influenza antibodies require Fc receptor engagement for in vivo protection. J. Clin. Investig. 2016, 126, 605-610. [CrossRef] [PubMed]

62. He, W.; Chen, C.-J.; Mullarkey, C.E.; Hamilton, J.R.; Wong, C.K.; Leon, P.E.; Uccellini, M.B.; Chromikova, V.; Henry, C.; Hoffman, K.W.; et al. Alveolar macrophages are critical for broadly-reactive antibody-mediated protection against influenza A virus in mice. Nat. Commun. 2017, 8, 846. [CrossRef]

63. El Bakkouri, K.; Descamps, F.; De Filette, M.; Smet, A.; Festjens, E.; Birkett, A.; Van Rooijen, N.; Verbeek, S.; Fiers, W.; Saelens, X. Universal Vaccine Based on Ectodomain of Matrix Protein 2 of Influenza A: Fc Receptors and Alveolar Macrophages Mediate Protection. J. Immunol. 2011, 186, 1022-1031. [CrossRef] [PubMed]

64. Yasui, F.; Kohara, M.; Kitabatake, M.; Nishiwaki, T.; Fujii, H.; Tateno, C.; Yoneda, M.; Morita, K.; Matsushima, K.; Koyasu, S.; et al. Phagocytic cells contribute to the antibody-mediated elimination of pulmonary-infected SARS coronavirus. Virology 2014, 454-455, 157-168. [CrossRef]

65. Koga, H.; Prost-Squarcioni, C.; Iwata, H.; Jonkman, M.F.; Ludwig, R.J.; Bieber, K. Epidermolysis Bullosa Acquisita: The 2019 Update. Front. Med. 2019, 5, 362. [CrossRef]

66. Hirose, M.; Kasprick, A.; Beltsiou, F.; Dieckhoff, K.S.; Schulze, F.S.; Samavedam, U.K.J.S.R.L.; Hundt, J.E.; Pas, H.H.; Jonkman, M.F.; Schmidt, E.; et al. Reduced Skin Blistering in Experimental Epidermolysis Bullosa Acquisita After Anti-TNF Treatment. Mol. Med. 2016, 22, 918-926. [CrossRef] [PubMed]

67. Kovacs, B.; Tillmann, J.; Freund, L.-C.; Nimmerjahn, F.; Sadik, C.D.; Bieber, K.; Ludwig, R.J.; Karsten, C.M.; Köhl, J. Fc $\gamma$ Receptor IIB Controls Skin Inflammation in an Active Model of Epidermolysis Bullosa Acquisita. Front. Immunol. 2020, 10, 3012. [CrossRef]

68. Stamatiades, E.G.; Tremblay, M.E.; Bohm, M.; Crozet, L.; Bisht, K.; Kao, D.; Coelho, C.; Fan, X.; Yewdell, W.T.; Davidson, A.; et al. Immune Monitoring of Trans-endothelial Transport by Kidney-Resident Macrophages. Cell 2016, 166, 991-1003. [CrossRef]

69. Kaneko, Y.; Nimmerjahn, F.; Madaio, M.P.; Ravetch, J.V. Pathology and protection in nephrotoxic nephritis is determined by selective engagement of specific Fc receptors. J. Exp. Med. 2006, 203, 789-797. [CrossRef]

70. Chauhan, P.; Hu, S.; Sheng, W.S.; Prasad, S.; Lokensgard, J.R. Modulation of Microglial Cell Fc $\gamma$ Receptor Expression Following Viral Brain Infection. Sci. Rep. 2017, 7, 41889. [CrossRef]

71. Bruggeman, C.W.; Houtzager, J.; Dierdorp, B.; Kers, J.; Pals, S.T.; Lutter, R.; van Gulik, T.; den Haan, J.M.M.; van den Berg, T.K.; van Bruggen, R.; et al. Tissue-specific expression of IgG receptors by human macrophages ex vivo. PLoS ONE 2019, 14, e0223264. [CrossRef]

72. Nagelkerke, S.Q.; Bruggeman, C.W.; den Haan, J.M.M.; Mul, E.P.J.; van den Berg, T.K.; van Bruggen, R.; Kuijpers, T.W. Red pulp macrophages in the human spleen are a distinct cell population with a unique expression of Fc- $\gamma$ receptors. Blood Adv. 2018, 2, 941-953. [CrossRef]

73. Unkeless, J.C. Characterization of a monoclonal antibody directed against mouse macrophage and lymphocyte Fc receptors. J. Exp. Med. 1979, 150, 580-596. [CrossRef] [PubMed] 
74. Biburger, M.; Trenkwald, I.; Nimmerjahn, F. Three blocks are not enough-Blocking of the murine IgG receptor Fc $\gamma$ RIV is crucial for proper characterization of cells by FACS analysis. Eur. J. Immunol. 2015, 45, 2694-2697. [CrossRef] [PubMed]

75. Deka, C.; Lehnert, B.E.; Lehnert, N.M.; Jones, G.M.; Sklar, L.A.; Steinkamp, J.A. Analysis of fluorescence lifetime and quenching of FITC-conjugated antibodies on cells by phase-sensitive flow cytometry. Cytometry 1996, 25, 271-279. [CrossRef] 